\title{
Oxidative modifications, mitochondrial dysfunction, and impaired protein degradation in Parkinson's disease: how neurons are lost in the Bermuda triangle
}

\author{
Kristen A Malkus ${ }^{1}$, Elpida Tsika ${ }^{1,2}$ and Harry Ischiropoulos*1,3,4
}

\begin{abstract}
Address: ${ }^{1}$ The Joseph Stokes Jr Research Institute, The Children's Hospital of Philadelphia, Philadelphia, Pennsylvania, USA, ${ }^{2}$ The Department of Molecular Biology and Genetics, Democritus University of Thrace, Alexandroupolis, Greece, ${ }^{3}$ Department of Pediatrics, The University of Pennsylvania, Philadelphia, Pennsylvania, USA and ${ }^{4}$ Department of Pharmacology, The University of Pennsylvania, Philadelphia, Pennsylvania, USA

Email: Kristen A Malkus - malkus@mail.med.upenn.edu; Elpida Tsika - tsika@email.chop.edu;

Harry Ischiropoulos* - ischirop@mail.med.upenn.edu

* Corresponding author
\end{abstract}

Published: 5 June 2009

Molecular Neurodegeneration 2009, 4:24 doi:10.1186/1750-1326-4-24
Received: 9 March 2009

Accepted: 5 June 2009

This article is available from: http://www.molecularneurodegeneration.com/content/4///24

(C) 2009 Malkus et al; licensee BioMed Central Ltd.

This is an Open Access article distributed under the terms of the Creative Commons Attribution License (http://creativecommons.org/licenses/by/2.0), which permits unrestricted use, distribution, and reproduction in any medium, provided the original work is properly cited.

\begin{abstract}
While numerous hypotheses have been proposed to explain the molecular mechanisms underlying the pathogenesis of neurodegenerative diseases, the theory of oxidative stress has received considerable support. Although many correlations have been established and encouraging evidence has been obtained, conclusive proof of causation for the oxidative stress hypothesis is lacking and potential cures have not emerged. Therefore it is likely that other factors, possibly in coordination with oxidative stress, contribute to neuron death. Using Parkinson's disease (PD) as the paradigm, this review explores the hypothesis that oxidative modifications, mitochondrial functional disruption, and impairment of protein degradation constitute three interrelated molecular pathways that execute neuron death. These intertwined events are the consequence of environmental exposure, genetic factors, and endogenous risks and constitute a "Bermuda triangle" that may be considered the underlying cause of neurodegenerative pathogenesis.
\end{abstract}

\section{Review}

A "Bermuda Triangle" of Insults Induces

Neurodegeneration

Understanding the molecular basis of neurodegenerative diseases has proven to be a major challenge, yet is vitally important because of the prevalence of these chronic conditions in the aging population. While diverse neurodegenerative disorders, which encompass Alzheimer's disease (AD), Parkinson's disease (PD), Huntington's disease (HD), and Amyotrophic Lateral Sclerosis (ALS), involve unique proteins and selectively disparate brain regions, they share two key features: formation of insoluble protein aggregates and neuron degeneration [1].
Therefore it is reasonable to speculate that a common causative process underlies the pathogenesis of neurodegenerative disorders. Specifically focusing on PD, this review proposes that neurodegeneration is due to three interrelated molecular mechanisms: oxidative modifications, mitochondrial dysfunction, and impaired protein degradation.

One possible unifying molecular mechanism that can induce both the formation of protein inclusions and neuron degeneration is the oxidative reactions derived from the production of reactive oxygen and nitrogen species. A substantial increase in oxidized proteins, lipids, and DNA 
has been found in postmortem brain tissue of PD patients as compared to age-matched disease-free subjects [2]. Although these observations do not demonstrate that oxidative processes are the sole cause of neuronal demise, they are consistent with data in animal and cellular model systems (reviewed below) that establish a role for oxidation in neurodegeneration and death.

The four electron reduction of oxygen to water is a fundamental biochemical process largely responsible for the survival of organisms in aerobic environments. Oxidation and reduction reactions are also important in the central nervous system for the formation and metabolic processing of catecholamines, for the production of signaling molecules such as nitric oxide, and for the metabolism of xenobiotics. The coupling of these enzymatic systems ensures that electrons are transferred to the desired substrate, avoiding partial reduction of oxygen to reactive species. However, inappropriate reduction of oxygen does occur occasionally, resulting in the production of superoxide and hydrogen peroxide.

Mitochondria are considered a key source of reactive species. Interruptions or disturbances in the electron transport chain allow electrons to be transferred and reduce molecular oxygen by one electron to form superoxide, or by two electrons to form hydrogen peroxide. In addition to generating ATP, mitochondria also play critical roles in regulating cellular viability. Therefore, functional compromise of this organelle has a large impact on oxidative homeostasis. To protect against reactive species, a network of antioxidant enzymes including $\mathrm{Cu}$, $\mathrm{Zn}$ superoxide dismutase (SOD) in the cytosol, Mn SOD in the mitochondria, peroxidases, and catalase secure conversion of these reactive species to water and therefore prevent adverse oxidation of cellular macromolecules.

How then do reactive species induce stress? The answer to this question is not entirely understood but several suggestions have been advanced. A significant increase in the rate of reactive species production, potentially coupled with a decline in the efficiency of the antioxidant networks that remove them may permit secondary reactions with cellular biomolecules (proteins, lipids, DNA/RNA) that result in undesired oxidations. While neuronal homeostasis can be disturbed by these oxidative modifications, protective mechanisms including protein degradation, lipid turnover, and DNA repair sustain cellular homeostasis by repairing or removing the oxidized macromolecules. However, compromise of these defense mechanisms - either by direct oxidative modification or indirectly by the inability to process oxidatively modified substrates - may render the cell incapable of efficiently removing oxidized biomolecules, resulting in their accumulation.
Alteration of protein folding and degradation, due to oxidative stress, mitochondrial dysfunction, or other factors has been strongly associated with neurodegenerative diseases. Protein aggregation is a hallmark of a diverse array of these late-onset neurodegenerative disorders, and thus factors that influence protein folding, processing, and clearance have been a focus of much research. Two major pathways are responsible for the degradation of cellular proteins: the ubiquitin-proteasome system (UPS) [3] and the autophagy-lysosome pathway [4-6].

The UPS is the principal mechanism of degradation for short-lived proteins and proteins that are misfolded in the endoplasmic reticulum [5]. UPS substrates are selectively targeted for degradation by the $20 \mathrm{~S}$ or $26 \mathrm{~S}$ proteasome complex after the conjugation of a polyubiquitin tag through a three-step enzymatic cascade [7]. Upon recruitment to the proteasome, the substrates must be unfolded to pass through the narrow barrel of the proteasome where they are degraded [5,7]. The consistent observation that antibodies against ubiquitin label some of the human and rodent protein inclusions suggests that failure of the UPS may contribute to neurodegeneration. However, the effect of UPS inhibition on cell death and protein aggregation in cellular model systems as well as rodent models has yielded conflicting results that have not been entirely resolved [8-13]. These variable results suggest that other factors, including other protein degradation pathways such as autophagy and mitochondrial dysfunction associated with a decline in ATP levels, may contribute to cellular viability. This hypothesis remains to be further explored in cellular and rodent model systems.

The other primary pathway for protein degradation in the cell is through autophagy. While the ultimate result of autophagy is always the delivery of proteins or organelles to the lysosome for degradation, there are three different routes by which this can be accomplished. Macroautophagy is a non-selective method of bulk degradation whose activity is upregulated in response to stress. Microautophagy is also a non-selective process, though it is maintained at a constitutively active state. The final type of autophagy is chaperone-mediated autophagy (CMA). Like macroautophagy, CMA is present at low basal levels in the cell and is upregulated in response to stress. However, CMA is unique from the other two forms of autophagy in that it is a selective process $[4,14]$. While the UPS, macroautophagy, and CMA have been implicated as potential contributors to neurodegeneration, their precise involvement is controversial and unclear.

Macroautophagy was first implicated in neurodegeneration after it was noted that autophagic structures were present in affected brain regions of patients with neurodegenerative diseases, including PD [15-18]. Initial hypoth- 
eses speculated that these autophagic vacuoles were evidence of neurons "eating themselves to death" [15]. This was based on previous observations that autophagic mechanisms can participate in induction of non-apoptotic cell death cascades [19-25]. However, recent evidence has shown that, particularly within the context of neurodegeneration, macroautophagy may instead serve as a protective process by which cells attempt to clear misfolded proteins and damaged organelles[4]. Independently generated data has revealed the neuroprotective role of macroautophagy through manipulation of either Atg7 or Atg5 - two different proteins essential for autophagy. Conditionally knocking out either of these genes in the central nervous system of mice leads to severe neurodegeneration and formation of protein inclusions, accompanied by motor dysfunction and early death $[26,27]$. In cells, inhibition of macroautophagy at the stage of autophagosome formation by 3-methyladenine (3-MA), at the stage of autophagosome-lysosome fusion by Bafilomycin A1 (BafA1), or at the stage of lysosomal degradation by deficiency of the enzyme cathepsin $\mathrm{D}$, led to enhanced aggregation of polygluatmine, polyalanine, and $\alpha$-synuclein proteins [28-30]. In contrast, the induction of autophagy leds to increased clearance and reduced toxicity of pathogenic proteins, decreased aggregate formation and neurodegeneration, and improved behavioral phenotype in fly and mouse models [29-35]. Stimulation of autophagy has been accomplished either by rapamycin, which inhibits the negative regulator of autophapgy mammalian target of rapamycin (mTOR), or by several mTOR independent compounds including lithium, trehalose, and small molecules identified in a screen [29-35].

CMA may also be playing a role in cell vulnerability. In CMA deficient cells, baseline levels of survival were unaffected, but stressors such as UV light or multiple types of oxidative stress significantly reduced viability [36]. Additionally, the proteins implicated in neurodegenerative disease, APP, Htt, and $\alpha$-synuclein, all contain a putative CMA targeting motif, indicating that regulation of this degradation system may have important effects on pathogenic protein homeostasis[14].

The UPS, macroautophagy, and CMA are each involved in the degradation of oxidized proteins. In response to moderate levels of oxidative stress, cells are able to induce a protective upregulation of all three of these protein degradation pathways, supporting an interplay between protein oxidation and protein degradation during normal homeostasis [4,37-43].

However, more severe oxidative stress impairs the degradation of oxidized proteins $[39,40,44]$. For the UPS system, oxidative modifications that induce crosslinking, misfolding, and aggregation prevent the proper unfolding necessary for substrates to be passed through the barrel of the proteasome for degradation, making these substrates resistant to degradation as well as potentially inhibiting the overall activity of the proteasome [45-48]. Additionally, direct oxidative modification of the proteasome subunits inhibits $20 \mathrm{~S}$ and $26 \mathrm{~S}$ catalytic peptidase activity [46,49-54]. In a rat model of ischemia/reperfusion, the lipid peroxidation product 4-hydroxyl-2-noneal (HNE) impaired the peptidase activity of the proteasome by direct oxidative modification of the $\alpha$-like $20 \mathrm{~S}$ proteasome subunits iota, C3, and an isoform of XAPC7 $[53,54]$.

Additionally, oxidatively modified proteins may impair the cellular machinery of autophagic degradation [55]. Reactive species can damage the lysosomal membrane and crosslink membrane proteins, resulting in cytosolic leakage of lysosomal hydrolases [56-58]. Some oxidatively modified aggregated species are resistant to degradation by proteases and accumulate within lysosomes. There, the non-degraded proteins become a potential new source of reactive species, further damaging the lysosomal membrane [59].

Below we discuss evidence that implicates known environmental, genetic, and endogenous factors as contributors that intitiate oxidative modifications, mitochondrial dysfunction, and protein aggregation in PD (Figure 1). We propose that the combined interactions of these three interrelated molecular pathways - oxidative modifications, mitochondrial dysfunction, and impaired protein degradation - constitute a "Bermuda Triangle" that ultimately induces neuron death.

\section{Environmental Toxins}

One of the most striking clues into the processes involved in PD came from the observation of rapid-onset motor impairments that replicated most of the features of sporadic $P D$ in individuals accidentally exposed to 1-Methyl4-phenyl-1,2,3,6-tetrahydropyridine (МРTP) [60]. Further epidemiological studies have suggested that exposure to other pesticides and environmental toxins are associated with PD development. Through their implied ability to target mitochondria, disrupt dopamine metabolism, and participate in the formation of oxidants, these toxins initiate a cascade of deleterious events that can cause the progressive degeneration observed in disease [61].

In addition to the prototypical example of MPTP, a host of other compounds that generate oxidative and nitrative stress (defined as the formation of nitric oxide-dependent oxidants) have been found to be harmful to neurons. These agents have been used for the creation of intoxication models in rodents and non-human primates that reproduce some of the neuropathological findings and behavioral symptoms of the human disease. These intox- 


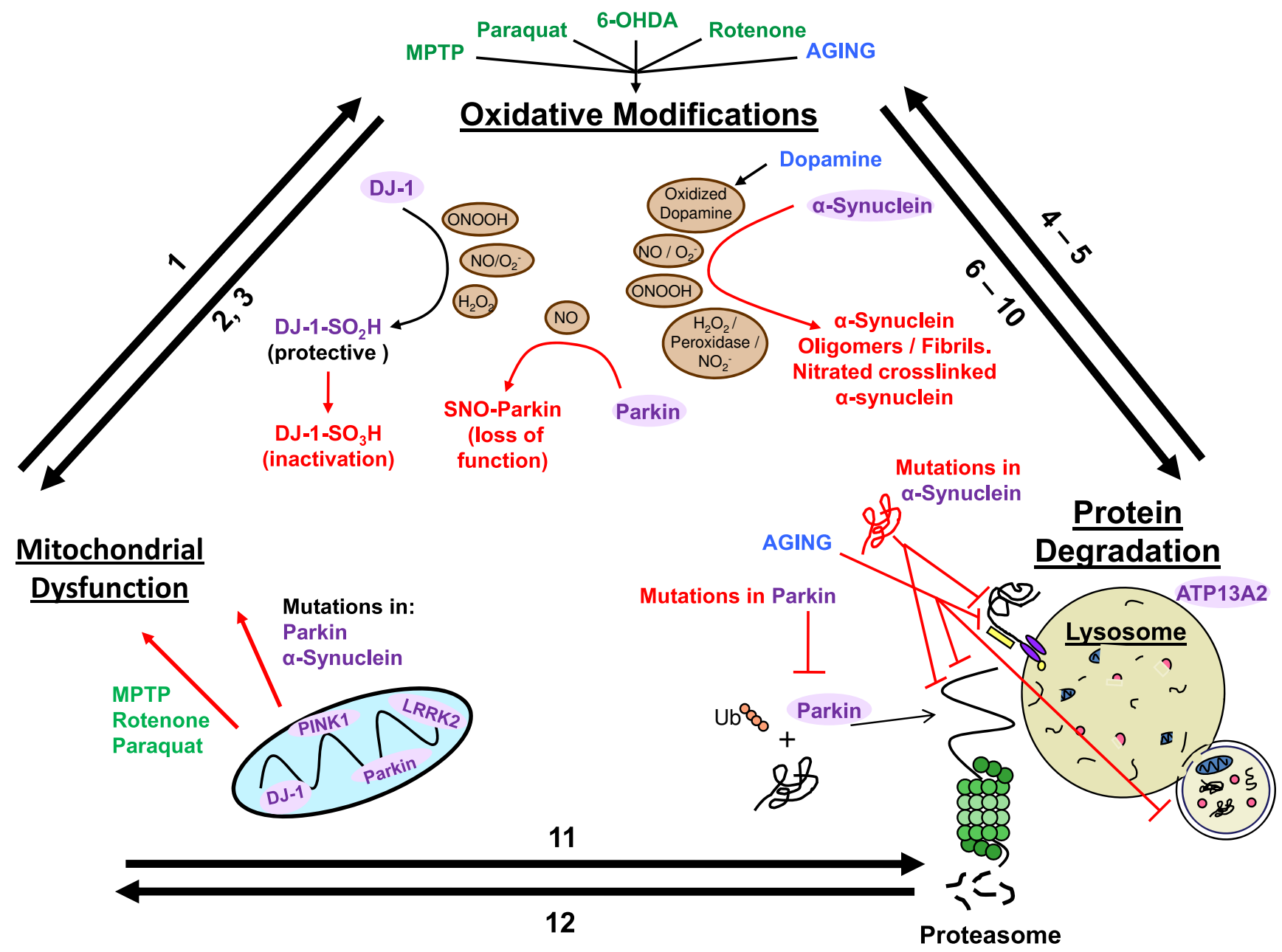

Figure I

A "Bermuda Triangle" of insults leads to neurondeath in PD. Known risk factors for the onset of Parkinson's disease (PD) include environmental (green), genetic (purple), and endogenous (blue) influences. Contributions from these risk factors trigger oxidative modifications, mitochondrial dysfunction, and impaired protein degradation that together form a "Bermuda triangle" of interrelated molecular events that underlie neurodegeneration. The interactions between these pathways are supported by the following (for details and citations, please refer to text): (I) Disturbances in mitochondrial respiration generate reactive oxygen species. (2) Overexpression of SOD is protective against mitochondrial toxins. (3) NOS deficiency or inhibition attenuates MPTP, paraquat, and rotenone toxicity. (4) Inhibition of degradation systems leads to increased sensitivity to oxidative stressors. (5) Impaired degradation leads to an accumulation of substrates, increasing the probability for oxidative modifications. (6) Excessive production of reactive oxygen and nitrogen species modifies proteins, leading to inactivation, crosslinking, and aggregation. (7) $\alpha$-Synuclein modified by oxidized dopamine impedes CMA. (8) Oxidative modifications modify the lysosomal membrane and crosslink membrane proteins. (9) UPS and CMA are not able to unfold and remove oxidatively proteins. (I0) Oxidative modification of proteasome subunits inhibits UPS function. (II) Macroautophagy is the principle mechanism for the degradation of damaged mitochondria. (12) Proteasome inhibition increases mitochondrial reactive species generation and decreases complex I and II activity.

ication models described below are valuable in understanding the role of oxidative mechanisms, mitochondrial dysfunction, and protein aggregation in neuron death and the selective vulnerability of the nigrostriatal pathway.

Mechanistically, MPP+, the active metabolite of MPTP, is selectively taken up by dopaminergic neurons where it is suggested to inhibit complex I of the mitochondrial respiratory chain, inhibit the uptake of dopamine, and participate in oxidation-reduction biochemistry [62]. МРTP administration, widely used in non-human primates and mice, has been shown to replicate many features of PD, including motor phenotype, degeneration of nigral dopaminergic neurons, and formation of $\alpha$-synuclein 
positive filamentous proteinaceous inclusions resembling Lewy Bodies [63-66].

The concept that oxidative processes are playing a major role in the demise of the catecholaminergic neurons is reinforced by data documenting that mice over-expressing the antioxidant protein cytosolic SOD1 [67] are protected against MPTP toxicity. Additionally, the contribution of reactive nitrogen species to MPTP-induced neuron injury is revealed by studies in nitric oxide synthase (NOS) deficient animals. MPTP toxicity is attenuated in either iNOS or $\mathrm{nNOS}$ deficient mice $[68,69]$ or mice that are treated with nNOS inhibitors $[70,71]$ suggesting that nitric oxidederived oxidants are participants in the oxidative and nitrative processes that lead to MPTP-induced neurodegeneration.

The herbicide paraquat, a biologically redox active molecule, is a toxin that has deleterious effects on neurons. Paraquat is used in mouse models of neurodegeneration and leads to reduced motor activity, cell death selectively within the dopaminergic neurons of the substantia nigra, and degeneration of the striatal fibers in a dose-dependent way $[72,73]$. Additionally, systemic administration of paraquat results in upregulation of $\alpha$-synuclein expression and the formation of aggregates [74], similar to changes that have been reported following administration of MPTP [75]. Overexpression of SOD in cells or mice has been shown to protect against paraquat toxicity, supporting the role of oxidative stress in neuron death [76-79]. Delivery of molecules with SOD/catalase and antioxidant scavenging capacity such as MnTBAP or EUK-189 were shown to have a similar effect [80-82], although recent studies have indicated that this protection against paraquat may be due to antioxidant-independent mechanisms of MnTBAP including prevention of mitochondrial $\mathrm{Ca}^{2+}$ accumulation $[83,84]$.

Rotenone is an insecticide that selectively inhibits mitochondrial complex I. It has been used in rat models to produce a Parkinson-like phenotype including selective degeneration of the dopaminergic neurons of the nigrostriatal region, motor impairment, and fibrillar inclusions [85]. Unlike MPTP, rotenone is highly lipophilic and consequently can enter any cell type [86]. Therefore, rotenone could potentially inhibit mitochondrial complex I throughout the brain. However, rats chronically infused with rotenone develop selective nigral degeneration and $\alpha$-synuclein positive, Lewy body-like inclusions indicating that dopaminergic cells are somehow exquisitely sensitive to mitochondrial impairment [85]. The molecular details underlying this inherent dopaminergic neuron vulnerability still require further investigation, and will be discussed below.
Finally, 6-hydroxydopamine (6-OHDA), a prototypical oxidative stress toxin used in animal models for over 30 years, mimics PD by causing degeneration of the dopaminergic neurons $[87,88]$. 6-OHDA is structurally similar to dopamine and norepinephrine and thus can accumulate in catecholaminergic cells. In the presence of oxygen and transition metals it oxidizes into para-quinone and hydrogen peroxide, with superoxide $\left(\mathrm{O}_{2}{ }^{-}\right)$and semi-quinone radicals as intermediate species of the reaction [89]. The generation of reactive species and strong electrophiles attacking nucleophilic groups and inactivating macromolecules have been shown to contribute to neurodegeneration $[87,88]$. Injection of 6 -OHDA in the substantia nigra of rats leads to rapid death of dopaminergic neurons, while injection in the stiatum induces a retrograde degeneration of the neurons in the substantia nigra [90-92].

\section{Genetic Links}

While the majority of PD cases are sporadic, rare instances of genetic heritability have helped to provide further insight into the mechanisms contributing to disease. Currently, thirteen genetic loci, denoted PARK1-13, have been associated with PD [93]. From these loci, six genes have been established as a causative factor of familial PD: $\alpha$-synuclein (PARK1/4), parkin (PARK2), PINK1 (PARK6), DJ-1 (PARK7), LRRK2 (PARK8), and ATP13A2 (PARK9) [93-95]. ATP13A2 is a lysosomal P-type ATPase that has been associated with a recessive juvenile form of PD [96]. A recent studies highlighted a genetic interaction between ATP13A2 and $\alpha$-synuclein and showed that ATP13A2 is able to modulate $\alpha$-synuclein toxicity [97]. However, while ATP13A2's lysosomal location reinforces the importance of autophagic degradation, this review will focus on the other five PD genes that have been most extensively investigated. Each of these five genes (DJ-1, PINK1, Parkin, LRRK2, and $\alpha$-synculein) has yielded data supporting critical associations with mitochondrial and oxidative processes and protein degradation.

\section{DJ-I}

Mutations and deletions in the gene encoding DJ-1 have been linked to recessive familial PD. DJ-1 is a mitochondrial-associated protein which has been suggested to function as an antioxidant with peroxidredoxin-like activity [98-100]. Mass spectrometry and other methodologies have indentified Cys106 in DJ-1 as the critical amino acid for DJ-1 mediated protection against oxidative stress as well as for the relocation of DJ-1 to the mitochondria during oxidative stress [101]. Irreversible oxidation of this residue renders the protein incapable of protecting cells from oxidant insults [102].

Support for a role of DJ-1 as a protective antioxidant protein is derived from experiments demonstrating that 
knockout/knockdown of DJ-1 or expression of DJ-1 with a pathogenic mutation in cells leads to an increased sensitivity to oxidative stress $[99,103]$. Similarly, increased sensitivity to neurotoxins that generate oxidative stress such as MPTP, rotenone, and paraquat has been documented in DJ-1 deficient drosophila and mice [104-108]. Correspondingly, over-expression of DJ-1 protects against oxidative insults. In dopaminergic cell lines, overexpression of wild type, but not mutant, DJ-1 was able to protect cells from hydrogen peroxide and 6-OHDA challenges, leading to reduced levels of reactive species, protein oxidation, and cell death $[109,110]$. In animal models, overexpression of wild type but not mutant DJ-1 was protective against dopaminergic neural degeneration in mice exposed to MPTP or rats exposed to 6-OHDA $[108,110,111]$.

\section{PINKI}

PTEN-induced kinase 1(PINK1) is a mitochondrial associated protein whose loss of function mutations lead to a recessive form of hereditary early onset PD [112]. PINK1 is a putative serine/threonine kinase with an N-terminal mitochondrial targeting sequence [113]. Both endogenous and recombinant PINK1 are localized to the mitochondria in cell culture and a drosophila model [112114]. Functionally, it is postulated that PINK1 phosphorylates mitochondrial proteins in response to cellular stress and thus protects against mitochondrial dysfunction $[112,115]$. Additional roles for PINK1 in regulating mitochondrial fusion and fission as well as modulating proteolytic activity through interaction with the serine protease HtrA2 have also been proposed [116-119]. Within the context of disease, lymphoblasts of patients with mutations in PINK1 show increased lipid peroxidation and defects in mitochondrial complex I activity $[120,121]$. Additionally, abnormal mitochondrial morphology was evident in primary cells derived from patients with two different mutations in PINK1 [120].

PINK1 has been shown to influence cell viability. Knockdown of PINK1 in SH-SY5Y, HeLa, and mouse primary neurons, caused abnormal mitochondrial morphology, compromised mitochondrial function, increased markers of oxidative stress, and ultimately decreased cell viability $[120,122]$. Additionally, those cells were more vulnerable to challenges by rotenone and the active metabolite of MPTP, MPP+ $[120,123,124]$. Conversely, overexpression of PINK1 in cell models protected against cell death induced by mitochondrial permeability transition pore opening, oxidative stress, and proteasome inhibitors. Protection of cellular viability was related to the ability of PINK1 to prevent loss of mitochondrial membrane potential, to suppress cytochrome c release from mitochondria, and suppress activation of caspase-3 $[112,115,125,126]$. Expression of PINK1 with pathogenic mutations, expres- sion of a truncated form of PINK1, or expression of PINK1 lacking the kinase domain eliminated this protective effect $[112,115,125,126]$.

Similar to the cell models, mitochondrial abnormalities and increased sensitivity to stressors have also been documented in PINK1 deficient drosophila [127-130]. This phenotype was able to be rescued by expression of wild type but not mutant PINK1 as well as by expression or administration of SOD-1, further supporting the view that the protective role of PINK1 is related to oxidative processes $[128,130]$.

Interestingly, PINK1 knockout mice do not display generalized mitochondrial defects [131]. However, impaired mitochondrial respiration does occur specifically within the nigrostriatal dopaminergic circuit, and mitochondria isolated from the knockout mice display increased sensitivity to hydrogen peroxide [132]. PINK1 knockout mice also have impaired dopamine release and impaired synaptic plasticity, suggesting a specific role in dopaminergic neuron function [131]. This has important implications for the specificity with which dopaminergic neurons are affected in PD.

\section{Parkin}

Identification of loss of function mutations in the gene encoding the ubiquitin ligase parkin in autosomal recessive PD indicates that dysfunction of the ubiquitin proteasome system is a contributing factor in the pathogenesis of PD [133-135]. Additionally, recent evidence implicates parkin in mitochondrial function and oxidative processes.

Parkin is localized to the mitochondria of proliferating cells and influences mitochondrial biogenesis [136]. Attempts to examine the effect of parkin modifications on other proteins have included two dimensional gel electrophoresis combined with proteomic analysis in parkin knockout mice, as well a genetic screen for parkin modifiers and the use of cDNA microarrays to characterize transcriptional alterations in parkin deficient drosophila [137-139]. These studies report that parkin modulates expression of proteins involved in the regulation of energy metabolism, such as subunits of pyruvate dehydrogenase, mitochondrial complexes I and IV, and ATP synthase, as well as in proteins involved protection against oxidative stress, such as peroxiredoxin 1, 2, and 6, Hsp70 related proteins, carbonyl reductase, and thioredoxin reductase $[137,138]$. Drosophila models deficient in parkin or expressing parkin with a pathogenic mutation exhibit mitochondrial dysfunction and alterations in oxidative response components $[139,140]$. Additionally, parkin deficient drosophila have increased sensitivity to paraquat [141]. In parkin knockout mice, impaired mitochondrial function and decreased antioxidant capacity is accompa- 
nied by nigrostriatal defects, synaptic dysfunction, and dopaminergic behavioral deficits $[138,142]$.

Parkin overexpression in cultured cells helped prevent mitochondrial swelling, cytochrome c release, caspase 3 activation, increased reactive species levels, and cell death $[143,144]$. In a murine model, viral overexpression of parkin was able to inhibit dopaminergic neural loss in mice exposed to MPTP [111]. As an E3 Ubiquitin ligase, parkin levels are upregulated in response to unfolded protein reponse stress induced by the application of the N-glycosylation inhibitor tunicamycin or the reducing agent 2mercaptoethanol [145]. Parkin overexpression correspondingly is able to rescue cells from the unfolded protein response (UPR) induced by various stressors [145]. Additionally, parkin overexpression has been shown to protect cells against proteasomal dysfunction and death induced by mutant $\alpha$-synuclein [146]

Oxidative modifications may also impact parkin itself. Snitrosylation, a nitric oxide-derived post-translational modification, of parkin occurs in vitro, in a mouse model of PD, and in the brains of PD patients [147]. S-nitrosylation decreases parkin's ubiquitin E3 ligase activity and its protective function in cells expressing $\alpha$-synuclein and synphilin-1 that were exposed to a proteasome inhibitor $[147,148]$. Such consequences provide a mechanism by which parkin's function may be disrupted and thus contribute to disease progression in sporadic PD. S-nitrosylation has also been shown to affect the activity of other proteins relevant to neurodegeneration, including protein-disulfide isomerase (PDI), an ER chaperone [149]. Snitrosylation inhibits PDI's enzymatic activity, preventing it from promoting the proper folding of proteins during times of cellular stress and preventing PDI's protective effect [149].

Recent studies have provided further support for the role of parkin in oxidative processes by establishing that parkin functions downstream of PINK1 within the same pathway. Drosophila mutants that are deficient in either parkin or PINK1 exhibit similar phenotypes. Transgenic expression of parkin is able to rescue the phenotype of PINK1 deficient flies, although the reverse is not true [127-129]. This downstream relationship is supported by the fact that in PINK1 deficient flies, the level of parkin protein is significantly reduced [128]. Additionally, it has been shown that DJ-1 with a pathogenic mutation is able to associate with parkin, and this association is promoted by oxidative stress [150].

\section{Leucine-rich repeat kinase 2}

Recently, leucine-rich repeat kinase 2 (LRRK2) has been recognized as a cause of an autosomal dominant lateonset form of familial PD. LRRK2 expression in the brain largely correlates to the nigrostriatal dopaminergic system, although diffuse expression throughout the brain has also been noted, including expression in the cerebral cortex, hippocampus, and cerebellum [151-154]. Within the cell, LRRK2 associates largely with membrane bound structures, including the mitochondria, lysosomes, plasma membrane, synaptic vesicles, golgi apparatus, and endoplasmic reticulum and is likely associated with lipid rafts in these membranes [154-156]. LRRK2 contains putative GTPase, protein kinase, WD40 repeat, and leucine-rich repeat (LRR) domains, but the endogenous function of the protein is still being investigated [157].

In support of the role of mutated LRRK2 in neurodegeneration, expression of LRRK2 with pathogenic mutations in SH-SY5Y cells and primary neurons reduced cell viability [155,158-160]. LRRK2 also affects the ability of the cell to handle oxidative stress. Overexpression of mutant LRRK2 failed to rescue cultured cells from hydrogen peroxide exposure, while expression of wild type LRRK2 successfully attenuated this stress [161]. Additionally, drosophila expressing mutant LRRK2 were significantly more sensitive to paraquat and hydrogen peroxide than flies expressing wild type LRRK2 or deficient in LRRK2 [162]. The magnitude of oxidative damage was lowest in drosophila deficient in LRRK2, while flies expressing the mutant LRRK2 had the highest levels [162]. While these observations support the dominant-negative effect of LRRK2 mutations, it is unclear why wild type LRRK2 is more detrimental than a deficiency of LRRK2. Further studies need to be conducted to fully understand both the normal and pathogenic function of this protein.

\section{$\alpha$-Synuclein}

In addition to the discovery that three different autosomal dominant missense mutations in the gene encoding $\alpha$ synuclein cause early onset, familial PD, wild type $\alpha$-synuclein has also been identified as one of the primary components of Lewy bodies in sporadic cases [163-167]. $\alpha$ Synuclein is a soluble, relatively unstructured protein, expressed throughout the central nervous system whose function relates to synaptic vesicular regulation and to chaperone-like activity [168-170]. A hydrophobic region spanning residues $71-82$, as well as factors that have not been fully understood, contribute to the orderly assembly of $\alpha$-synuclein into amyloid fibers that ultimately constitute in part the Lewy bodies and other inclusions [171173]. $\alpha$-Synuclein appears to both contribute to mitochondrial dysfunction, oxidative stress, and impaired protein degradation, as well as itself be a target for oxidative modifications that may affect aggregation and neurotoxicity.

In a cell model, overexpression of $\alpha$-synuclein led to mitochondrial dysfunction and increased levels of reactive spe- 
cies [174]. A similar effect was reported in transgenic mice expressing $\alpha$-synuclein with the A53T pathogenic mutation. These mice developed mitochondrial degeneration and cell death [175]. $\alpha$-Synuclein additionally appears to sensitize mice to mitochondrial toxins. Transgenic mice expressing mutant $\alpha$-synuclein had increased neural degeneration, mitochondrial abnormalities, $\alpha$-synuclein aggregation, and levels of oxidative and nitrative modifications after exposure to challenges including MPTP, paraquat and maneb [176-179]. Importantly, mice that lack $\alpha$-synuclein are protected against MPTP toxicity [180182 ]. Recent evidence has also shown that $\alpha$-synuclein accumulates within mitochondria due to an $\mathrm{N}$-terminal targeting sequence, leading to impaired mitochondrial complex I activity and increased production of reactive species [183]. Significantly more $\alpha$-synuclein was accumulated in mitochondria isolated from the substantia nigra and striatum of patients with sporadic PD than from controls [183].

$\alpha$-Synuclein may also play a role in disease through its effects on protein degradation. It has been suggested that $\alpha$-synuclein may initiate UPS inhibition, as it has been shown to disrupt the proteasome in vitro, an effect that is enhanced by the pathogenic $\alpha$-synuclein mutations $[146,184-186]$. The mechanisms underlying this inhibition are not fully understood, though possibilities include binding of $\alpha$-synuclein to a subunit of the proteasome, blockage of the proteasome by aggregated proteins, or potentially an unknown downstream mechanism. Additionally, $\alpha$-synuclein may play a role in autophagy. In vitro studies have shown $\alpha$-synuclein is preferentially degraded by CMA [187]. However pathogenic mutations of synuclein or modification by oxidized dopamine cause $\alpha$ synuclein to bind strongly to the lysosomal CMA receptor. This blocks the uptake and degradation of $\alpha$-synuclein and other CMA substrates $[55,187]$. Downstream effects of this disruption may explain how $\alpha$-synuclein mutations are able to induce cell death $-\alpha$-synuclein induced impaired CMA degradation of myocyte enhancer factor 2D (MEF2D), a transcription factor required for neuronal survival, resulting in the cytosolic accumulation of MEF2D that bound poorly to DNA, causing an overall decrease in MEF2D function [188].

While $\alpha$-synuclein can modulate mitochondrial function, oxidative challenges, and protein degradation machinery, oxidation and nitration also appear to modify $\alpha$-synuclein directly and consequently affect its aggregation. $\alpha$-Synuclein nitrated on tyrosine residues has been identified in the detergent-insoluble fraction of the brains of PD patients, suggesting that this modification may induce the aggregation of this protein or that aggregated forms of the protein are selectively modified by nitrating oxidants [189]. In cell, mouse, and non-human primate models, treatment with MPTP has been shown to increase oxidative modifications and aggregation of $\alpha$-synuclein $[64,75,190]$. Treatment of cells or rats with rotenone and mice with paraquat similarly increased $\alpha$-synuclein aggregation and inclusion formation and cellular dysfunction $[74,85,191]$.

Collectively, these findings led to biochemical examination of the effect of oxidative or nitrative modification on $\alpha$-synuclein. Fibrillar $\alpha$-syncuclein aggregates with a perinuclear localization were formed in cells expressing $\alpha$ syncuclein upon kinetically controlled exposure to nitric oxide and superoxide [192]. Studies with purified protein revealed that tyrosine nitration effects the ability of $\alpha$ synuclein to bind to lipid vesicles and slows the rate of degradation by the 20S proteasome and calpain-I [193]. Nitration of $\alpha$-synuclein monomers and dimers is able to accelerate the rate of fibril formation through the recruitment of non-nitrated $\alpha$-synuclein, but nitration of oligomers inhibits fibril formation [193-195]. In addition to nitration, exposure of $\alpha$-synuclein to nitrating oxidants also results in the formation of highly stable $o, o^{\prime}$-dityrosine cross linked dimers and oligomers [196]. $o, o^{\prime}$-Dityrosine cross linking was found to stabilize pre-formed fibrils, which significantly accelerate the formation of fibrilar aggregates. Site-directed mutation of the four tyrosine residues in $\alpha$-synuclein discerned that the tyrosine residues are essential for crosslinking and stabilization in response to nitrative insults. [196]. However, oxidative modifications also are able to affect $\alpha$-synuclein and invoke crosslinking and stable fibril formation independent of tyrosine residues [197]. The C-terminal of $\alpha$-synuclein has been found to be critical for oligomerization of $\alpha$-synuclein into detergent insoluble species in response to oxidation by copper and hydrogen peroxide [198].

Due to the regional specificity of pathology in PD patients, the effect of dopamine on $\alpha$-synuclein has also been investigated. During a chemical compound library screen for molecules that would inhibit formation of $\alpha$ synuclein fibrils, Lansbury and coworkers discovered that the neurotransmitter dopamine inhibits the formation of $\alpha$-synuclein fibrils [199]. The interaction of dopamine with $\alpha$-synuclein appeared to arrest the process of fibril formation at a stage of oligomeric species [199]. We have extended these observations to indicate that dopamine oxidation is essential for this kinetic arrest of $\alpha$-synuclein oligomers [200]. Since dopamine oxidation generates reactive species and strong electrophiles, mutational analysis of putative amino acid targets in $\alpha$-synuclein that could be modified by this oxidation was explored [200]. Examination of sites such as the three methionine residues and histidine 50 revealed that covalent modification of these amino acids was not responsible for the effects of oxidized dopamine [200]. The data indicated that the 
interaction of oxidized dopamine with $\alpha$-synuclein is directed, not towards a single amino acid, but rather five amino acid residues: tyrosine-glutamate-methionine-proline-serine (YEMPS) in position 125-129 in the C-terminus of the protein [200,201]. Recent studies have confirmed these findings and also indicated that the glutamate 83 residue also participates in stabilizing the interaction of oxidized dopamine with the YEMPS region [202]. The in vitro data has been confirmed in cellular model systems that express A53T $\alpha$-synuclein or A53T $\alpha$-synuclein with all 5 amino acids 125-129 mutated, establishing the importance of this $\mathrm{C}$ terminal region in the stabilization of $\alpha$-synuclein oligomers in the presence of oxidized dopamine $[201,203]$. The decrease in catecholamine levels that has been described as an early even in PD pathogenesis [204] may then allow the formation of insoluble $\alpha$-synuclein aggregates later in disease [203]. Additionally, $\alpha$-synuclein modified by oxidized dopamine may have deleterious effects on cellular function, indicating that aggregation may not be a necessary prerequisite for cell death. $\alpha$-Synuclein modified by oxidized dopamine has been shown to block CMA by binding strongly to the L2A receptor and blocking the uptake of itself and other substrates [55]. Oligomeric $\alpha$-synuclein was shown to bind to the lysosomal membrane but was unable to be unfolded or taken up into the lysosomes [55]. Furthermore, $\alpha$-synuclein modified by oxidized dopamine was able to decrease neuronal viability to a degree similar to the effect of L2A RNAi [55]. Therefore $\alpha$ synuclein may serve as both a modulator and a target of oxidative and nitrative modifications.

\section{Endogenous Factors}

In addition to evidence from genetic and environmental risks, the two endogenous factors of aging and dopamine oxidation have implicated oxidative modifications, mitochondrial dysfunction, and impaired protein degradation in PD.

\section{Aging}

In PD, the most significant risk factor for developing disease is age. The accumulation of proteins altered by oxidative modifications has been shown to increase with age, which correlates with the late-onset of neurodegenerative pathology $[205,206]$. Examination of cultured human fibroblasts, human brain tissue, as well as tissues from other organisms have shown that in elderly individuals, approximately one third of proteins have been oxidatively modified [206-208]. This increase is not linear but instead occurs as an initial gradual rise that magnifies several fold in late age [6,206-208]. Oxidative modifications most likely accumulate with age due to a combination of increased production of reactive species, decreased antioxidant function, and impaired ability to repair or remove the modified proteins.
Dysfunctional clearance has been largely supported by findings that the activities of the UPS, macroautophagy and CMA decline with age, consequently diminishing the ability of the cell to clear modified proteins or protect itself from damaging free radicals $[47,209-216]$. Due to impaired degradation, proteins with oxidative modifications accumulate in the cell, increasing their propensity for aggregation $[47,216]$. Additionally, once the activity of these degradation pathways is diminished, a feed-forward effect on oxidative damage may result. Sullivan et al. found that proteasomal inhibition increased mitochondrial reactive species generation and decreased mitochondrial complex I and II activity [217]. Therefore, inhibition of the proteasome and autophagy pathways may be further contributing to oxidative damage.

\section{Dopamine Oxidation}

The characteristic topology of cell loss that is revealed from neuropathological studies of PD brains, with the relatively selective vulnerability of the ventrolateral and caudal regions of the substantia nigra pars compacta, can provide useful clues on the etiology of the disease. In particular, it has been postulated that the oxidative environment of dopaminergic neurons might be a key component in the pathogenesis of PD. Typically, dopamine is rapidly sequestered within vesicles by the vesicular monoamine transporter, where the acidic $\mathrm{pH}$ significantly delays the oxidation of dopamine. However, an oxidative environment can be created if dopamine remains in the cytosol, where it can oxidize at physiological $\mathrm{pH}$ to generate reactive ortho-quinones, aminochromes, as well as superoxide and hydrogen peroxide $[218,219]$. Excessive cytosolic oxidation of catechols has been shown to be neurotoxic in cell culture and rodent models [220-222]. However, it is unclear whether intracellular oxidation of dopamine is able to significantly contribute to the neuron injury.

The gradual accumulation of oxidized dopamine that occurs in normal aging does not appear sufficient to induce neuronal death. However, a consequence of the accrual of oxidized dopamine is the formation of neuromelanin. Neuromelanin, the substance that gives the dopaminergic neurons of the substantia nigra their characteristic dark appearance, is a polymer of oxidized and subsequently heterocyclized dopamine. It has been proposed that the polymer is sequestered within the neurons to form a new cellular organelle of unknown function [223]. In that capacity it has been hypothesized that the neuromelanin polymer might be neuroprotective by further chelating toxins and transition metals such as iron and manganese [223-226]. Since divalent redox capable metals such as iron participate in catalytic reactions with hydrogen peroxide to generate potent oxidizing species, such a role would be crucial to protecting neurons. Efforts 
to limit the availability of iron have been found to protect neurons from injury and death [227-230].

Alternatively, other studies have revealed a correlation in PD brains between cell loss and the presence of neuromelanin, which suggests that the neuromelanin-pigmented subpopulation of dopaminergic neurons are more vulnerable in disease [231]. Another interesting but unexplored observation is the co-localization of the characteristic protein inclusions (Lewy bodies) in close proximity to neuromelanin in human post mortem PD brains $[232,233]$. It is possible that the synthesis of neuromelanin, which requires the oxidation of dopamine and the formation of oxidants and electrophiles, promotes the formation of protein aggregates by oxidizing proteins, providing a scaffold for protein filament assembly, or both. In support of its role as a scaffold for aggregation, the melanosome has been shown to be crucial for the assembly of the nonpathogenic natively amyloidogenic protein Pmel17 [234]. Additionally, the melanosome precursor itself assembles into amyloid-like fibrils that may promote the association and assembly of other amyloidogenic proteins [235]. Aggregation may also been promoted by the raft like lipid component of neuromelanin, as hydrophobic interactions would bring macromolecules in close proximity $[235,236]$. Another interesting observation is that the presence of neuromelanin in dopaminergic neurons is unique to primates, which may explain inconsistencies in the attempts to recapitulate disease in rodent models [237-240].

\section{Conclusion}

Examining the "Bermuda triangle" in which dopamine neurons are lost, oxidative modifications, mitochondrial dysfunction, and impaired protein degradation appear to be three interrelated molecular pathways responsible for the pathogenesis of both sporadic and familial PD (Figure 1). Evidence from environmental, genetic, and endogenous factors highlights the interplay of these three mechanisms as the common detrimental denominators inducing neuronal death. Not only do these three processes have clear impacts on cellular viability, but their participation explains other characteristic features of disease, such as the presence of oxidized proteins, inclusions, increased prevalence with late age, and dopaminergic regional selectivity. Together, through their effects on cellular homeostasis and their interactions with one another, oxidative stress, mitochondrial dysfunction, and impaired protein degradation provide the final impetus with which insult to neurons is transformed into neurodegenerative disease.

Currently, treatment for PD is focused merely on alleviating symptoms. As research progresses towards a better understanding of the molecular mechanisms underlying disease, hopefully a more effective therapy can ultimately be designed. Current trials to deliver compounds that can restore mitochondrial function and reduce oxidative burden will be informative and not only improve therapeutic treatment of PD but also provide vital results to guide future studies investigating the molecular mechanisms of neurodegeneration.

\section{Abbreviations}

PD: Parkinson's Disease; UPS: Ubiquitin Proteasome System; CMA: Chaperone Mediated Autophagy; MPTP: 1methyl-4-phenyl-1,2,3,6-tetrahydropyridine; 6-OHDA: 6Hydroxy Dopamine; PINK1: PTEN-Induced Kinase 1; LRRK2: Leucine-Rich Repeat Kinase 2; SOD: Superoxide dismutase; NOS: Nitric oxide synthase.

\section{Competing interests}

The authors declare that they have no competing interests.

\section{Authors' contributions}

$\mathrm{KAM}, \mathrm{ET}$, and HI wrote the manuscript.

\section{Acknowledgements}

This work is supported by NIH grants AGI3966 and ESOI 3508 NIEHS Center of Excellence in Environmental Toxicology. $\mathrm{HI}$ is the Gisela and Dennis Alter Chair in Pediatric Neonatology at the Children's Hospital of Philadelphia.

\section{References}

I. Merlini G, Bellotti V: Molecular mechanisms of amyloidosis. $N$ Engl J Med 2003, 349:583-596.

2. Jenner $P$, Olanow $C W$ : Oxidative stress and the pathogenesis of Parkinson's disease. Neurology 1996, 47:SI6I-SI70.

3. Storch A, Jost WH, Vieregge P, Spiegel I, Greulich W, Durner I, Muller T, Kupsch A, Henningsen H, Oertel WH, Fuchs G, Kuhn W, Niklowitz P, Koch R, Herting B, Reichmann H, German Coenzyme, QSG: Randomized, double-blind, placebo-controlled trial on symptomatic effects of coenzyme $Q(10)$ in Parkinson disease. Arch Neurol 2007, 64(7):938-944.

4. Bandhyopadhyay $U$, Cuervo AM: Chaperone-mediated autophagy in aging and neurodegeneration: lessons from alpha-synuclein. Exp Geront 2007, 42:120-128.

5. Rubinsztein DC: The roles of intracellular protein-degradation pathways in neurodegeneration. Nature 2006, 443:780-786.

6. Keller JN, Dimayuga E, Chen Q, Thorpe J, Gee J, Ding Q: Autophagy, proteasomes, lipofuscin, and oxidative stress in the aging brain. Int J Biochem Cell Biol 2004, 36:2376-2391.

7. Ross CA, Pickart CM: The ubiquitin-proteasome pathway in Parkinson's disease and other neurodegenerative diseases. Trends Cell Biol 2004, 14:703-7II.

8. McNaught KSP, Perl DP, Brownell A-L, Olanow CW: Systemic exposure to proteasome inhibitors causes a progressive model of Parkinson's disease. Ann Neurol 2004, 56: |49-I62.

9. Zeng B-Y, Bukhatwa S, Hikima A, Rose S, Jenner P: Reproducible nigral cell loss after systemic proteasomal inhibitor administration to rats. Ann Neurol 2006, 60:248-252.

10. Schapira AHV, Cleeter MWJ, Muddle JR, Workman JM, Cooper JM, King RHM: Proteasomal inhibition causes loss of nigral tyrosine hydroxylase neurons. Ann Neurol 2006, 60:253-255.

II. Manning-Bog A, Reaney SH, Chou VP, Johnston LC, McCormack AL, Johnston J, Langston JW, Monte DAD: Lack of nigrostriatal pathology in a rat model of proteasome inhibition. Ann Neurol 2006, 60:256-260.

12. Bove J, Zhou C, Jackson-Lewis V, Taylor J, Chu Y, Rideout HJ, Wu DC, Kordower JH, Petrucelli L, Przedborski S: Proteasome inhibi- 
tion and Parkinson's disease modeling. Ann Neurol 2006, 60:260-264.

13. Kordower JH, Kanaan NM, Chu Y, Babu RS, III JS, Terpstra BT, Sortwell CE, Steece-Collier K, Collier TJ: Failure of proteasome inhibitor administration to provide a model of Parkinson's disease in rats and monkeys. Ann Neurol 2006, 60:264-268.

14. Massey A, Kiffin R, Cuervo AM: Pathophysiology of chaperonemediated autophagy. Int J Biochem Cell Biol 2004, 36:2420-2434.

15. Anglade P, Vyas S, Javoy-Agid F, Herrero MT, Michel PP, Marquez J, Mouatt-Prigent A, Ruberg M, Hirsch EC, Agid Y: Apoptosis and autophagy in nigral neurons of patients with Parkinson's disease. Histol Histopathol. 1997, I 2(I):25-3I.

16. Nixon RA, Wegiel J, Kumar A, Yu WH, Peterhoff C, Cataldo A, Cuervo AM: Extensive involvement of autophagy in Alzheimer disease: an immuno-electron microscopy study. J Neuropathol Exp Neurol. 2005, 64(2): I I3-122.

17. Sapp E, Schwarz C, Chase K, Bhide PG, Young AB, Penney J, Vonsattel $J P$, Aronin N, DiFiglia M: Huntingtin localization in brains of normal and Huntington's disease patients. Ann Neurol 1997, 42:604-6I2.

18. Cataldo AM, Hamilton DJ, Barnett JL, Paskevich PA, Nixon RA: Properties of the endosomal-lysosomal system in the human central nervous system: disturbances mark most neurons in populations at risk to degenerate in Alzheimer's disease. J Neurosci. 1996, 16(1):186-199.

19. Hornung J, Koppel H, Clarke P: Endocytosis and autophagy in dying neurons: an ultrastructural study in chick embryos. J Comp Neurol 1989, 283:425-437.

20. Xue L, Fletcher GC, Tolkovsky AM: Autophagy Is Activated by Apoptotic Signalling in Sympathetic Neurons: An Alternative Mechanism of Death Execution. Molecular and Cellular Neuroscience 1999, 14:180-198.

21. Yue Z, Horton A, Bravin M, Dejager PL, Selimi F, Heintz N: A Novel Protein Complex Linking the [delta]2 Glutamate Receptor and Autophagy: Implications for Neurodegeneration in Lurcher Mice. Neuron 2002, 35:921-933.

22. Borsello T, Croquelois K, Hornung J-P, Clarke PGH: N-methyl-daspartate-triggered neuronal death in organotypic hippocampal cultures is endocytic, autophagic and mediated by the c-Jun N-terminal kinase pathway. Eur J Neurosci 2003, I 8:473-485.

23. Yu L-Y, Jokitalo E, Sun Y-F, Mehlen P, Lindholm D, Saarma M, Arumae $U:$ GDNF-deprived sympathetic neurons die via a novel nonmitochondrial pathway. J Cell Biol 2003, 163:987-997.

24. Yu L, Alva A, Su H, Dutt P, Freundt E, Welsh S, Baehrecke EH, Lenardo MJ: Regulation of an ATG7-beclin I Program of Autophagic Cell Death by Caspase-8. Science 2004, 304:1500-1502.

25. Shimizu S, Kanaseki T, Mizushima N, Mizuta T, Arakawa-Kobayashi S, Thompson CB, Tsujimoto $\mathrm{Y}$ : Role of $\mathbf{B c l}-2$ family proteins in a non-apoptotic programmed cell death dependent on autophagy genes. Nat Cell Biol 2004, 6:I22I-I 228.

26. Hara $T$, Nakamura $K$, Matsui $M$, Yamamoto $A$, Nakahara $Y$, SuzukiMigishima R, Yokoyama M, Mishima K, Saito I, Okano H, Mizushima $\mathrm{N}$ : Suppression of basal autophagy in neural cells causes neurodegenerative disease in mice. Nature 2006, 44I:885-889.

27. Komatsu M, Waguri S, Chiba T, Murata S, Iwata J-i, Tanida I, Ueno T, Koike M, Uchiyama Y, Kominami E, Tanaka K: Loss of autophagy in the central nervous system causes neurodegeneration in mice. Nature 2006, 44I:880-884.

28. Qin Z-H, Wang Y, Kegel KB, Kazantsev A, Apostol BL, Thompson LM, Yoder J, Aronin N, Difiglia M: Autophagy regulates the processing of amino terminal huntingtin fragments. Hum Mol Genet 2003, I 2:323।-3244.

29. Ravikumar B, Duden R, Rubinsztein DC: Aggregate-prone proteins with polyglutamine and polyalanine expansions are degraded by autophagy. Hum Mol Genet 2002, I I:I I07-I I I7.

30. Webb JL, Ravikumar B, Atkins J, Skepper JN, Rubinsztein DC: \{alpha\}-Synuclein Is Degraded by Both Autophagy and the Proteasome. I Biol Chem 2003, 278:25009-250I3.

31. Sarkar S, Floto RA, Berger Z, Imarisio S, Cordenier A, Pasco M, Cook LJ, Rubinsztein DC: Lithium induces autophagy by inhibiting inositol monophosphatase. J Cell Biol 2005, I70: I I0I-IIII.

32. Sarkar S, Davies JE, Huang Z, Tunnacliffe A, Rubinsztein DC: Trehalose, a Novel mTOR-independent Autophagy Enhancer,
Accelerates the Clearance of Mutant Huntingtin and \{alpha\}-Synuclein. J Biol Chem 2007, 282:564I-5652.

33. Sarkar S, Perlstein EO, Imarisio S, Pineau S, Cordenier A, Maglathlin RL, Webster JA, Lewis TA, O'Kane CJ, Schreiber SL, Rubinsztein DC: Small molecules enhance autophagy and reduce toxicity in Huntington's disease models. Nat Chem Biol 2007, 3:33I-338.

34. Berger Z, Ravikumar B, Menzies FM, Oroz LG, Underwood BR, Pangalos MN, Schmitt I, Wullner U, Evert BO, O'Kane C], Rubinsztein DC: Rapamycin alleviates toxicity of different aggregateprone proteins. Hum Mol Genet 2006, 15:433-442.

35. Ravikumar B, Vacher C, Berger Z, Davies JE, Luo S, Oroz LG, Scaravilli F, Easton DF, Duden R, O'Kane C], Rubinsztein DC: Inhibition of $m$ TOR induces autophagy and reduces toxicity of polyglutamine expansions in fly and mouse models of Huntington disease. Nat Genet 2004, 36:585-595.

36. Massey AC, Kaushik S, Sovak G, Kiffin R, Cuervo AM: Consequences of the selective blockage of chaperone-mediated autophagy. Proc Natl Acad Sci USA 2006, 103:5805-58I0.

37. McCray BA, Taylor JP: The role of autophagy in age-related neurodegeneration. Neurosignals. 2008, I6(I):75-84.

38. Kiffin R, Christian C, Knecht E, Cuervo AM: Activation of chaperone-mediated autophagy during oxidative stress. Mol Biol Cell 2004, 15:4829-4840.

39. Grune T, Reinheckel T, Joshi M, Davies KJ: Proteolysis in cultured liver epithelial cells during oxidative stress. Role of the multicatalytic proteinase complex, proteasome. J Biol Chem 1995, 270:2344-235I

40. Grune T, Blasig IE, Sitte N, Roloff B, Haseloff R, Davies KJ: Peroxynitrite increases the degradation of aconitase and other cellular proteins by proteasome. J Biol Chem 1998, 273: $10857-10862$.

4I. Davies KJ: Degradation of oxidized proteins by the $20 \mathrm{~S}$ proteasome. Biochimie 200I, 83:30I-3I0.

42. Grune T, Reinheckel T, Davies KJ: Degradation of oxidized proteins in $\mathrm{K562}$ human hematopoietic cells by proteasome. J Biol Chem 1996, 27 I: I5504-15509.

43. Sitte N, Merker K, Grune T: Proteasome-dependent degradation of oxidized proteins in MRC-5 fibroblasts. FEBS lett 1998 , 440:399-402

44. Ullrich O, Reinheckel T, Sitte N, Grune T: Degradation of hypochlorite-damaged glucose-6-phosphate dehydrogenase by the 20 S proteasome. Free Radic Biol Med 1999, 27:487-492.

45. Friguet B, Szweda LI: Inhibition of the multicatalytic proteinase (proteasome) by 4-hydroxy-2-nonenal cross-linked protein. FEBS lett 1997, 405:21-25.

46. Friguet B, Stadtman ER, Szweda LI: Modification of glucose-6phosphate dehydrogenase by 4-hydroxy-2-nonenal. Formation of cross-linked protein that inhibits the multicatalytic protease. J Biol Chem. 1994, 269(24):21639-2I643.

47. Sitte N, Merker K, Von Zglinicki T, Grune T, Davies KJ: Protein oxidation and degradation during cellular senescence of human BJ fibroblasts: part I-effects of proliferative senescence. Faseb J 2000, 14:2495-2502.

48. Sitte N, Huber M, Grune T, Ladhoff A, Doecke W-D, Von Zglinicki T, Davies KJA: Proteasome inhibition by lipofuscin/ceroid during postmitotic aging of fibroblasts. FASEB J 2000, 14:1490-1498.

49. Keller JN, Huang FF, Dimayuga ER, Maragos WF: Dopamine induces proteasome inhibition in neural $\mathrm{PC} / 2$ cell line. Free Radic Biol Med 2000, 29:1037-1042.

50. Keller JN, Huang FF, Markesbery WR: Decreased levels of proteasome activity and proteasome expression in aging spinal cord. Neuroscience 2000, 98:149-156.

5I. Keller JN, Huang FF, Zhu H, Yu J, Ho YS, Kindy TS: Oxidative stress-associated impairment of proteasome activity during ischemia-reperfusion injury. I Cereb Blood Flow Metab 2000, 20:1467-I473.

52. Shamoto-Nagai M, Maruyama W, Kato $Y$, Isobe K, Tanaka M, Naoi M, Osawa T: An inhibitor of mitochondrial complex I, rotenone inactivates proteasome by oxidative modification and induces aggregation of oxidized proteins in SH-SY5Y cells. J Neurosci Res 2003, 74:589-597.

53. Okada K, Wangpoengtrakul C, Osawa T, Toyokuni S, Tanaka K, Uchida K: 4-Hydroxy-2-nonenal-mediated impairment of intracellular proteolysis during oxidative stress. Identification of proteasomes as target molecules. I Biol Chem 1999, 274:23787-23793. 
54. Bulteau AL, Lundberg KC, Humphries KM, Sadek HA, Szweda PA, Friguet B, Szweda LI: Oxidative modification and inactivation of the proteasome during coronary occlusion/reperfusion. J Biol Chem 200I, 276:30057-30063.

55. Martinez-Vicente M, Talloczy Z, Kaushik S, Massey AC, Mazzulli J, Mosharov EV, Hodara R, Fredenburg R, Wu DC, Follenzi A, Dauer W, Przedborski S, Ischiropoulos H, Lansbury PT, Sulzer D, Cuervo AM: Dopamine-modified alpha-synuclein blocks chaperonemediated autophagy. J Clin Invest. 2008, I I 8(2):777-788.

56. Wan FY, Wang YN, Zhang GJ: The influence of oxidation of membrane thiol groups on lysosomal proton permeability. Biochem / 200I, 360:355-362.

57. Brunk UT, Dalen H, Roberg K, Hellquist HB: Photo-oxidative disruption of lysosomal membranes causes apoptosis of cultured human fibroblasts. Free Radic Biol Med 1997, 23:616-626.

58. Brunk UT, Terman A: Lipofuscin: mechanisms of age-related accumulation and influence on cell function. Free Radic Biol Med 2002, 33:611-619.

59. Ditaranto K, Tekirian TL, Yang AJ: Lysosomal membrane damage in soluble Abeta-mediated cell death in Alzheimer's disease. Neurobiol Dis 200I, 8:|9-3।.

60. Langston JW, Ballard P, Tetrud JW, Irwin I: Chronic Parkinsonism in Humans due to a Product of Meperidine-Analog Synthesis. Science 1983, 21 9:979-980.

61. Olanow CW, Tatton WG: Etiology and pathogenesis of Parkinson's disease. Annu Rev Neurosci 1999, 22:123-144.

62. Choi WS, Kruse SE, Palmiter RD, Xia Z: Mitochondrial complex I inhibition is not required for dopaminergic neuron death induced by rotenone, MPP+, or paraquat. Proc Natl Acad Sci USA 2008, 105:15136-15|4|.

63. Forno LS, Langston JW, DeLanney LE, Irwin I: An electron microscopic study of MPTP-induced inclusion bodies in an old monkey. Brain Res 1988, 448:150-I57.

64. Kowall NW, Hantraye P, Brouillet E, Beal MF, McKee AC, Ferrante $R J$ : MPTP induces alpha-synuclein aggregation in the substantia nigra of baboons. Neuroreport 2000, I I:2। I-2I3.

65. Forno L, Langston J, DeLanney L, Irwin I, Ricaurte G: Locus ceruleus lesions and eosinophilic inclusions in MPTP-treated monkeys. Ann Neurol 1986, 20:449-455.

66. Moratalla R, Quinn B, DeLanney LE, Irwin I, Langston JW, Graybiel AM: Differential vulnerability of primate caudate-putamen and striosome-matrix dopamine systems to the neurotoxic effects of I-methyl-4-phenyl-I,2,3,6-tetrahydropyridine. Proc Natl Acad Sci USA 1992, 89:3859-3863.

67. Przedborski S, Chen Q, Vila M, Giasson BI, Djaldatti R, Vukosavic S, Souza JM, Jackson-Lewis V, Lee VM, Ischiropoulos H: Oxidative post-translational modifications of alpha-synuclein in the Imethyl-4-phenyl-I,2,3,6-tetrahydropyridine (MPTP) mouse model of Parkinson's disease. J Neurochem 200I, 76:637-640.

68. Liberatore GT, Jackson-Lewis V, Vukosavic S, Mandir AS, Vila M, McAuliffe WG, Dawson VL, Dawson TM, Przedborski S: Inducible nitric oxide synthase stimulates dopaminergic neurodegeneration in the MPTP model of Parkinson disease. Nat Med 1999, 5:1403.

69. Matthews RT, Beal MF, Fallon J, Fedorchak K, Huang PL, Fishman MC, Hyman BT: MPP+Induced Substantia Nigra Degeneration Is Attenuated in nNOS Knockout Mice. Neurobiol Dis 1997, 4:|| $|4-| 2 \mid$.

70. Schulz BJ, Henshaw DR, Matthews RT, Beal MF: Coenzyme QI0 and nicotinamide and a free radical spin trap protect against MPTP neurotoxicity. Exp Neurol 1995, 132:279-283.

7I. Przedborski S, Jackson-Lewis V, Yokoyama R, Shibata T, Dawson VL, Dawson TM: Role of neuronal nitric oxide in I-methyl-4-phenyl-1,2,3,6-tetrahydropyridine (MPTP)-induced dopaminergic neurotoxicity. Proc Natl Acad Sci USA 1996, 93:4565-457I.

72. Brooks Al, Chadwick CA, Gelbard HA, Cory-Slechta DA, Federoff $\mathrm{HJ}$ : Paraquat elicited neurobehavioral syndrome caused by dopaminergic neuron loss. Brain Res 1999, 823:1-10.

73. McCormack AL, Thiruchelvam M, Manning-Bog AB, Thiffault C, Langston JW, Cory-Slechta DA, Di Monte DA: Environmental Risk Factors and Parkinson's Disease: Selective Degeneration of Nigral Dopaminergic Neurons Caused by the Herbicide Paraquat. Neurobiol Dis 2002, 10:1 19-127.

74. Manning-Bog AB, McCormack AL, Li J, Uversky VN, Fink AL, Di Monte DA: The herbicide paraquat causes up-regulation and aggregation of alpha-synuclein in mice: paraquat and alphasynuclein. J Biol Chem 2002, 277: 164I-1644.

75. Vila M, Vukosavic S, Jackson-Lewis V, Neystat M, Jakowec M, Przedborski S: Alpha-Synuclein Up-Regulation in Substantia Nigra Dopaminergic Neurons Following Administration of the Parkinsonian Toxin MPTP. J Neurochem 2000, 74:721-729.

76. Elroy-Stein O, Bernstein Y, Groner Y: Overproduction of human $\mathrm{Cu} / \mathrm{Zn}$-superoxide dismutase in transfected cells: extenuation of paraquat-mediated cytotoxicity and enhancement of lipid peroxidation. EMBO J. 1986, 5(3):615-622.

77. St. Clair DK, Oberley TD, Ho Y-S: Overproduction of human Mn-superoxide dismutase modulates paraquat-mediated toxicity in mammalian cells. FEBS lett I991, 293:199-203.

78. Thiruchelvam M, Prokopenko O, Cory-Slechta DA, Richfield EK, Buckley B, Mirochnitchenko O: Overexpression of Superoxide Dismutase or Glutathione Peroxidase Protects against the Paraquat + Maneb-induced Parkinson Disease Phenotype. J Biol Chem 2005, 280:22530-22539.

79. Dong A, Shen J, Krause M, Akiyama H, Hackett SF, Lai H, Campochiaro PA: Superoxide dismutase I protects retinal cells from oxidative damage. J Cell Physiol 2006, 208:516-526.

80. Patel M, Day BJ, Crapo JD, Fridovich I, McNamara JO: Requirement for Superoxide in Excitotoxic Cell Death. Neuron 1996, 16:345-355.

8I. Day BJ, Shawen S, Liochev SI, Crapo JD: A metalloporphyrin superoxide dismutase mimetic protects against paraquatinduced endothelial cell injury in vitro. J Pharmacol Exp Ther. 1995, 275(3): I 227-I 232.

82. Peng J, Stevenson FF, Doctrow SR, Andersen JK: Superoxide Dismutase/Catalase Mimetics Are Neuroprotective against Selective Paraquat-mediated Dopaminergic Neuron Death in the Substantial Nigra: Implications For Parkinson Disease. J Biol Chem 2005, 280:29194-29198.

83. Tauskela JS, Brunette E, O'Reilly N, Mealing G, Comas T, Gendron TF, Monette R, Morley P: An alternative Ca2+-dependent mechanism of neuroprotection by the metalloporphyrin class of superoxide dismutase mimetics. FASEB J. 2005, 19(12): 1734-1736.

84. Rebouças J, Spasojević I, Batinić-Haberle I: Pure manganese(III) $5,10,15,20$-tetrakis(4-benzoic acid)porphyrin (MnTBAP) is not a superoxide dismutase mimic in aqueous systems: a case of structure-activity relationship as a watchdog mechanism in experimental therapeutics and biology. J Biol Inorg Chem 2008, 13:289-302.

85. Betarbet R, Sherer TB, MacKenzie G, Garcia-Osuna M, Panov AV, Greenamyre JT: Chronic systemic pesticide exposure reproduces features of Parkinson's disease. Nat Neurosci 2000, 3:1301-1306

86. Dauer W, Przedborski S: Parkinson's disease: mechanisms and models. Neuron 2003, 39:889-909.

87. Dunnett SB, Bjorklund A: Prospects for new restorative and neuroprotective treatments in Parkinson's disease. (cover story). Nature 1999, 399:A32.

88. Jenner $\mathrm{P}$, Olanow CW: Understanding cell death in Parkinson's disease. Ann Neurol. 1998, 44(3 Suppl I):S72-S84.

89. Cohen G, Heikkila RE, MacNamee D: The Generation of Hydrogen Peroxide Superoxide Radical and Hydroxyl Radical by 6Hydroxydopamine Dialuric Acid and Related Cytotoxic Agents. J Biol Chem 1974, 249(8):2447-2452

90. Jeon BS, Jackson-Lewis V, Burke RE: 6-Hydroxydopamine lesion of the rat substantia nigra: time course and morphology of cell death. Neurodegeneration 1995, 4:131-137.

91. Sauer H, Oertel WH: Progressive degeneration of nigrostriatal dopamine neurons following intrastriatal terminal lesions with 6-hydroxydopamine: A combined retrograde tracing and immunocytochemical study in the rat. Neuroscience 1994 , 59:40I-4I5.

92. Przedbroski S, Leviver M, Jiang H, Ferreira M, Jackson-Lewis V, Donaldson D, Togasaki DM: Dose-dependent lesions of the dopaminergic nigrostriatal pathway induced by instrastriatal injection of 6-hydroxydopamine. Neuroscience 1995, 67:631-647.

93. Thomas B, Beal MF: Parkinson's disease. Hum Mol Genet 2007, 16(Spec No 2):R 183-194. 
94. Lesage S, Brice A: Parkinson's disease: from monogenic forms to genetic susceptibility factors. Hum Mol Genet 2009, I 8:R48-59.

95. Gasser T: Mendelian forms of Parkinson's disease. Biochim Biophys Acta 2009 in press.

96. Ramirez A, Heimbach A, Grundemann J, Stiller B, Hampshire D, Cid LP, Goebel I, Mubaidin AF, Wriekat A-L, Roeper J, Al-Din A, Hillmer AM, Karsak M, Liss B, Woods CG, Behrens MI, Kubisch C: Hereditary parkinsonism with dementia is caused by mutations in ATP13A2, encoding a lysosomal type 5 P-type ATPase. Nat Genet 2006, 38: II84-II9I.

97. Gitler A, Chesi A, Geddie M, Strathearn K, Hamamichi S, Hill K, Caldwell K, Caldwell G, Cooper A, Rochet J, Lindquist S: Alpha-synuclein is part of a diverse and highly conserved interaction network that includes PARK9 and manganese toxicity. Nat Genet 2009, $41: 308-315$

98. Andres-Mateos E, Perier C, Zhang L, Blanchard-Fillion B, Greco TM, Thomas B, Ko HS, Sasaki M, Ischiropoulos H, Przedborski S, Dawson TM, Dawson VL: DJ-I gene deletion reveals that $D J-I$ is an atypical peroxiredoxin-like peroxidase. Proc Natl Acad Sci USA 2007, I04: | 4807-I 48I2.

99. Taira T, Saito Y, Niki T, Iguchi-Ariga SM, Takahashi K, Ariga H: DJ-I has a role in antioxidative stress to prevent cell death. EMBO $\operatorname{Rep}$ 2004, 5:213-218.

100. Mitsumoto A, Nakagawa $Y$, Takeuchi A, Okawa K, Iwamatsu A, Takanezawa Y: Oxidized forms of peroxiredoxins and DJ-I on two-dimensional gels increased in response to sublethal levels of paraquat. Free Radic Res 200I, 35:30I-3I0.

101. Canet-Aviles RM, Wilson MA, Miller DW, Ahmad R, McLendon C, Bandyopadhyay S, Baptista MJ, Ringe D, Petsko GA, Cookson MR: The Parkinson's disease protein $\mathrm{DJ}-\mathrm{I}$ is neuroprotective due to cysteine-sulfinic acid-driven mitochondrial localization. Proc Natl Acad Sci USA 2004, 10 1:9103-9108.

102. Meulener MC, Xu K, Thomson L, Ischiropoulos H, Bonini NM: Mutational analysis of $\mathrm{DJ}-\mathrm{I}$ in Drosophila implicates functional inactivation by oxidative damage and aging. Proc Natl Acad Sci USA 2006, 103:12517-12522.

103. Martinat C, Shendelman S, Jonason A, Leete T, Beal MF, Yang L, Floss $\mathrm{T}$, Abeliovich A: Sensitivity to oxidative stress in DJ-I-deficient dopamine neurons: an ES- derived cell model of primary Parkinsonism. PLoS biology 2004, 2:e327.

104. Yang Y, Gehrke S, Haque ME, Imai Y, Kosek J, Yang L, Beal MF, Nishimura I, Wakamatsu K, Ito S, Takahashi R, Lu B: Inactivation of Drosophila DJ-I leads to impairments of oxidative stress response and phosphatidylinositol 3-kinase/Akt signaling. Proc Natl Acad Sci USA 2005, 102: 13670-13675.

105. Meulener M, Whitworth AJ, Armstrong-Gold CE, Rizzu P, Heutink P, Wes PD, Pallanck LJ, Bonini NM: Drosophila DJ-I mutants are selectively sensitive to environmental toxins associated with Parkinson's disease. Curr Biol 2005, 15:1572-1577.

106. Park J, Kim SY, Cha GH, Lee SB, Kim S, Chung J: Drosophila DJ-I mutants show oxidative stress-sensitive locomotive dysfunction. Gene 2005, 361:133-139.

107. Menzies FM, Yenisetti SC, Min KT: Roles of Drosophila DJ-I in survival of dopaminergic neurons and oxidative stress. Curr Biol 2005, 15:1578-1582.

108. Kim RH, Smith PD, Aleyasin H, Hayley S, Mount MP, Pownall S, Wakeham A, You-Ten AJ, Kalia SK, Horne P, Westaway D, Lozano AM, Anisman H, Park DS, Mak TW: Hypersensitivity of DJ-I-deficient mice to I-methyl-4-phenyl-I,2,3,6-tetrahydropyrindine (MPTP) and oxidative stress. Proc Natl Acad Sci USA 2005, 102:5215-5220.

109. Zhou W, Freed CR: DJ-I up-regulates glutathione synthesis during oxidative stress and inhibits A53T alpha-synuclein toxicity. J Biol Chem 2005, 280:43 I 50-43 I 58.

1 10. Inden M, Taira T, Kitamura Y, Yanagida T, Tsuchiya D, Takata K, Yanagisawa D, Nishimura K, Taniguchi T, Kiso Y, Yoshimoto K, Agatsuma T, Koide-Yoshida S, Iguchi-Ariga SM, Shimohama S, Ariga H: PARK7 DJ-I protects against degeneration of nigral dopaminergic neurons in Parkinson's disease rat model. Neurobiol Dis 2006 , 24:144-158.

III. Paterna JC, Leng A, Weber E, Feldon J, Bueler H: DJ-I and Parkin modulate dopamine-dependent behavior and inhibit MPTPinduced nigral dopamine neuron loss in mice. Mol Ther 2007, 1 5:698-704.
1 12. Valente EM, Abou-Sleiman PM, Caputo V, Muqit MM, Harvey K, Gispert S, Ali Z, Del Turco D, Bentivoglio AR, Healy DG, Albanese A, Nussbaum R, Gonzalez-Maldonado R, Deller T, Salvi S, Cortelli P, Gilks WP, Latchman DS, Harvey RJ, Dallapiccola B, Auburger G, Wood NW: Hereditary early-onset Parkinson's disease caused by mutations in PINK I. Science 2004, 304:I I58-I I60.

I 13. Sim CH, Lio DS, Mok SS, Masters CL, Hill AF, Culvenor JG, Cheng HC: C-terminal truncation and Parkinson's disease-associated mutations down-regulate the protein serine/threonine kinase activity of PTEN-induced kinase- I. Hum Mol Genet 2006, 15:3251-3262.

114. Silvestri L, Caputo V, Bellacchio E, Atorino L, Dallapiccola B, Valente EM, Casari G: Mitochondrial import and enzymatic activity of PINKI mutants associated to recessive parkinsonism. Hum Mol Genet 2005, 14:3477-3492.

II5. Petit A, Kawarai T, Paitel E, Sanjo N, Maj M, Scheid M, Chen F, Gu Y, Hasegawa H, Salehi-Rad S, Wang L, Rogaeva E, Fraser P, Robinson B, St George-Hyslop P, Tandon A: Wild-type PINKI prevents basal and induced neuronal apoptosis, a protective effect abrogated by Parkinson disease-related mutations. I Biol Chem 2005, 280:34025-34032.

I 16. Deng H, Dodson MW, Huang H, Guo M: The Parkinson's disease genes pink $\mathrm{I}$ and parkin promote mitochondrial fission and/ or inhibit fusion in Drosophila. Proc Natl Acad Sci USA 2008, 105: | 14503-14508.

117. Poole AC, Thomas RE, Andrews LA, McBride HM, Whitworth AJ, Pallanck LJ: The PINKI/Parkin pathway regulates mitochondrial morphology. Proc Natl Acad Sci USA 2008, 105:1638-1643.

I I8. Yang Y, Ouyang Y, Yang L, Beal MF, McQuibban A, Vogel H, Lu B: Pink I regulates mitochondrial dynamics through interaction with the fission/fusion machinery. Proc Natl Acad Sci USA 2008, 105:7070-7075.

1 19. Plun-Favreau H, Klupsch K, Moisoi N, Gandhi S, Kjaer S, Frith D, Harvey $K$, Deas E, Harvey RJ, McDonald N, Wood NW, Martins LM, Downward J: The mitochondrial protease HtrA2 is regulated by Parkinson's disease-associated kinase PINKI. Nat Cell Biol 2007, 9: $1243-1252$.

120. Exner N, Treske B, Paquet D, Holmstrom K, Schiesling C, Gispert S, Carballo-Carbajal I, Berg D, Hoepken HH, Gasser T, Kruger R, Winklhofer KF, Vogel F, Reichert AS, Auburger G, Kahle PJ, Schmid B, Haass C: Loss-of-function of human PINKI results in mitochondrial pathology and can be rescued by parkin. J Neurosci 2007, 27:|24|3-|24|8.

121. Hoepken HH, Gispert S, Morales B, Wingerter O, Del Turco D, Mulsch A, Nussbaum RL, Muller K, Drose S, Brandt U, Deller T, Wirth B, Kudin AP, Kunz WS, Auburger G: Mitochondrial dysfunction, peroxidation damage and changes in glutathione metabolism in PARK6. Neurobiol Dis 2007, 25:40I-4II.

122. Wood-Kaczmar A, Gandhi S, Yao Z, Abramov AS, Miljan EA, Keen G, Stanyer L, Hargreaves I, Klupsch K, Deas E, Downward J, Mansfield L, Jat P, Taylor J, Heales S, Duchen MR, Latchman D, Tabrizi SJ, Wood NW: PINKI is necessary for long term survival and mitochondrial function in human dopaminergic neurons. PLOS ONE 2008, 3:e2455.

123. Deng H, Jankovic J, Guo Y, Xie W, Le W: Small interfering RNA targeting the PINKI induces apoptosis in dopaminergic cells SH-SY5Y. Biochem Biophys Res Commun 2005, 337: I I 33-I I 38.

124. Tang $B$, Xiong $H$, Sun $P$, Zhang $Y$, Wang D, Hu Z, Zhu Z, Ma H, Pan $\mathrm{Q}$, Xia JH, Xia K, Zhang Z: Association of PINKI and DJ-I confers digenic inheritance of early-onset Parkinson's disease. Hum Mol Genet 2006, 15:1816-1825.

125. Pridgeon JW, Olzmann JA, Chin LS, Li L: PINKI Protects against Oxidative Stress by Phosphorylating Mitochondrial Chaperone TRAPI. PLoS biology 2007, 5:e I72.

126. Wang HL, Chou AH, Yeh TH, Li AH, Chen YL, Kuo YL, Tsai SR, Yu ST: PINKI mutants associated with recessive Parkinson's disease are defective in inhibiting mitochondrial release of cytochrome c. Neurobiol Dis 2007, 28:216-226.

127. Park J, Lee SB, Lee S, Kim Y, Song S, Kim S, Bae E, Kim J, Shong M, Kim JM, Chung J: Mitochondrial dysfunction in Drosophila PINKI mutants is complemented by parkin. Nature 2006, 44I: II I57-II6I.

128. Yang Y, Gehrke S, Imai Y, Huang Z, Ouyang Y, Wang JW, Yang L, Beal MF, Vogel H, Lu B: Mitochondrial pathology and muscle and dopaminergic neuron degeneration caused by inactivation of 
Drosophila PinkI is rescued by Parkin. Proc Natl Acad Sci USA 2006, 103: 10793-10798

129. Clark IE, Dodson MW, jiang C, Cao JH, Huh JR, Seol JH, Yoo SJ, Hay BA, Guo M: Drosophila pinkI is required for mitochondrial function and interacts genetically with parkin. Nature 2006, 44I: II62-II66.

130. Wang D, Qian L, Xiong H, Liu J, Neckameyer WS, Oldham S, Xia K, Wang J, Bodmer R, Zhang Z: Antioxidants protect PINKIdependent dopaminergic neurons in Drosophila. Proc Natl Acad Sci USA 2006, 103:13520-13525.

131. Kitada T, Pisani A, Porter DR, Yamaguchi H, Tscherter A, Martella G, Bonsi P, Zhang C, Pothos EN, Shen J: Impaired dopamine release and synaptic plasticity in the striatum of PINKI-deficient mice. Proc Natl Acad Sci USA 2007, 1 04: I | 44 |- I | 446.

132. Gautier CA, Kitada T, Shen J: Loss of PINKI causes mitochondrial functional defects and increased sensitivity to oxidative stress. Proc Natl Acad Sci USA 2008, I 05: I I 364-I I 369.

133. Kitada T, Asakawa S, Hattori N, Matsumine $H$, Yamamura $Y$, Minoshima S, Yokochi M, Mizuno Y, Shimizu N: Mutations in the parkin gene cause autosomal recessive juvenile parkinsonism. Nature 1998, 392:605-608.

134. Shimura H, Hattori N, Kubo S-i, Mizuno Y, Asakawa S, Minoshima S, Shimizu N, Iwai K, Chiba T, Tanaka K, Suzuki T: Familial Parkinson disease gene product parkin is a ubiquitin-protein ligase. Nat Genet 2000, 25:302-305.

135. Zhang Y, Gao J, Chung KKK, Huang H, Dawson VL, Dawson TM: Parkin functions as an E2-dependent ubiquitin- protein ligase and promotes the degradation of the synaptic vesicle-associated protein CDCrel-I. Proc Natl Acad Sci USA 2000, 97:13354-13359.

136. Kuroda Y, Mitsui T, Kunishige M, Shono M, Akaike M, Azuma H, Matsumoto T: Parkin enhances mitochondrial biogenesis in proliferating cells. Hum Mol Genet 2006, I5:883-895.

137. Periquet M, Corti O, Jacquier S, Brice A: Proteomic analysis of parkin knockout mice: alterations in energy metabolism, protein handling and synaptic function. J Neurochem 2005, 95: I259- 1276.

138. Palacino JJ, Sagi D, Goldberg MS, Krauss S, Motz C, Wacker M, Klose J, Shen J: Mitochondrial dysfunction and oxidative damage in parkin-deficient mice. J Biol Chem 2004, 279:|86|4-|8622.

139. Greene JC, Whitworth AJ, Andrews LA, Parker TJ, Pallanck LJ: Genetic and genomic studies of Drosophila parkin mutants implicate oxidative stress and innate immune responses in pathogenesis. Hum Mol Genet 2005, I4:799-8I I.

140. Greene JC, Whitworth AJ, Kuo I, Andrews LA, Feany MB, Pallanck LI: Mitochondrial pathology and apoptotic muscle degeneration in Drosophila parkin mutants. Proc Natl Acad Sci USA 2003, 100:4078-4083.

14I. Pesah Y, Pham T, Burgess H, Middlebrooks B, Verstreken P, Zhou Y, Harding M, Bellen H, Mardon G: Drosophila parkin mutants have decreased mass and cell size and increased sensitivity to oxygen radical stress. Development 2004, 1 31:2183-2194.

142. Goldberg MS, Fleming SM, Palacino IJ, Cepeda C, Lam HA, Bhatnagar A, Meloni EG, Wu N, Ackerson LC, Klapstein GJ, Gajendiran M, Roth BL, Chesselet MF, Maidment NT, Levine MS, Shen J: Parkin-deficient mice exhibit nigrostriatal deficits but not loss of dopaminergic neurons. J Biol Chem 2003, 278:43628-43635.

143. Darios F, Corti O, Lucking CB, Hampe C, Muriel MP, Abbas N, Gu W], Hirsch EC, Rooney T, Ruberg M, Brice A: Parkin prevents mitochondrial swelling and cytochrome c release in mitochondria-dependent cell death. Hum Mol Genet 2003, I 2:517-526.

144. Jiang H, Ren Y, Zhao J, Feng J: Parkin protects human dopaminergic neuroblastoma cells against dopamine-induced apoptosis. Hum Mol Genet 2004, I 3: I 745-I 754.

145. Imai Y, Soda M, Takahashi R: Parkin Suppresses Unfolded Protein Stress-induced Cell Death through Its E3 Ubiquitin-protein Ligase Activity. J Biol Chem 2000, 275:3566I-35664.

146. Petrucelli L, O'Farrell C, Lockhart PJ, Baptista M, Kehoe K, Vink L, Choi P, Wolozin B, Farrer M, Hardy J, Cookson MR: Parkin Protects against the Toxicity Associated with Mutant [alpha]Synuclein: Proteasome Dysfunction Selectively Affects Catecholaminergic Neurons. Neuron 2002, 36:1007-1019.

147. Chung KK, Thomas B, Li X, Pletnikova O, Troncoso JC, Marsh L, Dawson VL, Dawson TM: S-nitrosylation of parkin regulates ubiquitination and compromises parkin's protective function. Science 2004, 304:|328-|33|.

148. Yao D, Gu Z, Nakamura T, Shi Z-Q, Ma Y, Gaston B, Palmer LA, Rockenstein EM, Zhang Z, Masliah E, Uehara T, Lipton SA: Nitrosative stress linked to sporadic Parkinson's disease: S-nitrosylation of parkin regulates its E3 ubiquitin ligase activity. Proc Natl Acad Sci USA 2004, I 0 I: 108I0-108|4.

149. Uehara T, Nakamura T, Yao D, Shi ZQ, Gu Z, Ma Y, Masliah E, Nomura $Y$, Lipton SA: S-nitrosylated protein-disulphide isomerase links protein misfolding to neurodegeneration. Nature 2006, 44 I:5। 3-5I7.

150. Moore D, Zhang L, Troncoso J, Lee MK, Hattori N, Mizuno Y, Dawson TM, Dawson VL: Association of DJ-I and parkin mediated by pathogenic $\mathrm{DJ}-\mathrm{I}$ mutations and oxidative stress. Hum Mol Genet 2005, 14:7I-84.

15I. Galter D, Westerlund M, Carmine A, Lindqvist E, Sydow O, Olson L: LRRK2 expression linked to dopamine-innervated areas. Ann Neurol 2006, 59:7|4-7|9.

152. Higashi S, Moore DJ, Colebrooke RE, Biskup S, Dawson VL, Arai H, Dawson TM, Emson PC: Expression and localization of Parkinson's disease-associated leucine-rich repeat kinase 2 in the mouse brain. J Neurochem 2007, 100:368-381.

153. Higashi S, Biskup S, West AB, Trinkaus D, Dawson VL, Faull RLM, Waldvogel HJ, Arai H, Dawson TM, Moore DJ, Emson PC: Localization of Parkinson's disease-associated LRRK2 in normal and pathological human brain. Brain Res 2007, I I 55:208-219.

154. Biskup S, Moore DJ, Celsi F, Higashi S, West AB, Andrabi SA, Kurkinen K, Yu S-W, Savitt JM, Waldvogel HJ, Faull RLM, Emson PC, Torp R, Ottersen OP, Dawson TM, Dawson VL: Localization of LRRK2 to membranous and vesicular structures in mammalian brain. Ann Neurol 2006, 60:557-569.

155. West AB, Moore DJ, Biskup S, Bugayenko A, Smith WW, Ross CA, Dawson VL, Dawson TM: Parkinson's disease-associated mutations in leucine-rich repeat kinase $\mathbf{2}$ augment kinase activity. Proc Natl Acad Sci USA 2005, 102:16842-16847.

156. Hatano T, Kubo S-i, Imai S, Maeda M, Ishikawa K, Mizuno Y, Hattori $\mathrm{N}$ : Leucine-rich repeat kinase 2 associates with lipid rafts. Hum Mol Genet 2007, 16:678-690.

157. MacLeod D, Dowman J, Hammond R, Leete T, Inoue K, Abeliovich A: The familial Parkinsonism gene LRRK2 regulates neurite process morphology. Neuron 2006, 52:587-593.

158. Greggio E, Jain S, Kingsbury A, Bandopadhyay R, Lewis P, Kaganovich A, Brug MP van der, Beilina A, Blackinton J, Thomas KJ, Ahmad R, Miller DW, Kesavapany S, Singleton A, Lees A, Harvey RJ, Harvey K, Cookson MR: Kinase activity is required for the toxic effects of mutant LRRK2/dardarin. Neurobiol Dis 2006, 23:329-34I.

159. Smith WW, Pei Z, Jiang H, Moore DJ, Liang Y, West AB, Dawson VL, Dawson TM, Ross CA: Leucine-rich repeat kinase 2 (LRRK2) interacts with parkin, and mutant LRRK2 induces neuronal degeneration. Proc Natl Acad Sci USA 2005, 102: I8676-I868I.

160. Tan EK, Zhao Y, Skipper L, Tan MG, Di Fonzo A, Sun L, Fook-Chong S, Tang S, Chua E, Yuen Y, Tan L, Pavanni R, Wong MC, Kolatkar P, Lu CS, Bonifati V, Liu J]: The LRRK2 Gly2385Arg variant is associated with Parkinson's disease: genetic and functional evidence. Hum Genet 2007, I 20:857-863.

161. Liou AK, Leak RK, Li L, Zigmond MJ: Wild-type LRRK2 but not its mutant attenuates stress-induced cell death via ERK pathway. Neurobiol Dis 2008, 32:116-124.

162. Imai Y, Gehrke S, Wang HQ, Takahashi R, Hasegawa K, Oota E, Lu B Phosphorylation of 4E-BP by LRRK2 affects the maintenance of dopaminergic neurons in Drosophila. EMBO J 2008, 27:2432-2443.

163. Spillantini MG, Schmidt ML, Lee VM, Trojanowski JQ, Jakes R, Goedert M: Alpha-synuclein in Lewy bodies. Nature 1997, 388:839-840.

164. Polymeropoulos MH, Lavedan C, Leroy E, Ide SE, Dehejia A, Dutra A, Pike B, Root H, Rubenstein J, Boyer R, Stenroos ES, Chandrasekharappa S, Athanassiadou A, Papapetropoulos T, Johnson WG, Lazzarini AM, Duvoisin RC, Di lorio G, Golbe LI, Nussbaum RL: Mutation in the alpha-synuclein gene identified in families with Parkinson's disease. Science 1997, 276:2045-2047.

165. Kruger R, Kuhn W, Muller T, Woitalla D, Graeber M, Kosel S, Przuntek H, Epplen JT, Schols L, Riess O: Ala30Pro mutation in the gene encoding alpha-synuclein in Parkinson's disease. Nat Genet 1998, 18:106-108. 
166. Zarranz JJ, Alegre J, Gomez-Esteban JC, Lezcano E, Ros R, Ampuero I, Vidal L, Hoenicka J, Rodriguez O, Atares B, Llorens V, Gomez Tortosa E, del Ser T, Munoz DG, de Yebenes JG: The new mutation, E46K, of alpha-synuclein causes Parkinson and Lewy body dementia. Ann Neurol 2004, 55: I64-I73.

167. Chartier-Harlin M-C, Kachergus J, Roumier C, Mouroux V, Douay X, Lincoln S, Levecque C, Larvor L, Andrieux J, Hulihan M, Waucquier N, Defebvre L, Amouyel P, Farrer M, DestËe A: [alpha]-synuclein locus duplication as a cause of familial Parkinson's disease. Lancet 2004, 364: I I67-I 169.

168. Iwai A, Masliah E, Yoshimoto M, Ge N, Flanagan L, Rohan de Silva HA, Kittel A, Saitoh T: The precursor protein of non-A[beta] component of Alzheimer's disease amyloid is a presynaptic protein of the central nervous system. Neuron 1995, 14:467-475.

169. Chandra S, Gallardo G, Fernandez-Chacon R, Schluter OM, Sudhof TC: Alpha-synuclein cooperates with CSPalpha in preventing neurodegeneration. Cell 2005, I 23:383-396.

170. Maroteaux L, Campanelli JT, Scheller RH: Synuclein: a neuronspecific protein localized to the nucleus and presynaptic nerve terminal. J Neurosci. I988, 8(8):2804-28I5.

17I. Giasson BI, Murray IV, Trojanowski JQ, Lee VM: A hydrophobic stretch of 12 amino acid residues in the middle of alpha-synuclein is essential for filament assembly. I Biol Chem 200I, 276:2380-2386.

172. Conway KA, Lee S-J, Rochet J-C, Ding TT, Williamson RE, Lansbury PT: Acceleration of oligomerization, not fibrillization, is a shared property of both $\alpha$-synuclein mutations linked to early-onset Parkinson's disease: Implications for pathogenesis and therapy. Proc Natl Acad Sci USA 2000, 97:57|-576.

173. Goldberg MS, Lansbury PT Jr: Is there a cause-and-effect relationship between [alpha]-synuclein fibrillization and Parkinson/'s disease? Nat Cell Biol 2000, 2:EI I5-EII9.

174. Hsu LJ, Sagara Y, Arroyo A, Rockenstein E, Sisk A, Mallory M, Wong J, Takenouchi T, Hashimoto M, Masliah E: Alpha-Synuclein Promotes Mitochondrial Deficit and Oxidative Stress. Am J Pathol. 2000, I 57(2):401-4I0.

175. Martin LJ, Pan Y, Price AC, Sterling W, Copeland NG, Jenkins NA Price DL, Lee MK: Parkinson's disease alpha-synuclein transgenic mice develop neuronal mitochondrial degeneration and cell death. J Neurosci 2006, 26:4I-50.

176. Song DD, Shults CW, Sisk A, Rockenstein E, Masliah E: Enhanced substantia nigra mitochondrial pathology in human alphasynuclein transgenic mice after treatment with MPTP. Exp Neurol 2004, 186: I58-172.

177. Nieto M, Gil-Bea FJ, Dalfo E, Cuadrado M, Cabodevilla F, Sanchez B, Catena S, Sesma T, Ribe E, Ferrer I, Ramlrez MJ, Gomez-Isla T: Increased sensitivity to MPTP in human [alpha]-synuclein A30P transgenic mice. Neurobiol Aging 2006, 27:848-856.

178. Yu W, Matsuoka Y, Sziráki I, Hashim A, LaFrancois J, Sershen H, Duff K: Increased Dopaminergic Neuron Sensitivity to I-Methyl4-Phenyl-I,2,3,6-Tetrahydropyridine (MPTP) in Transgenic Mice Expressing Mutant A53T $\alpha$-Synuclein. Neurochem Res 2008, 33:902-911.

179. Norris EH, Uryu K, Leight S, Giasson BI, Trojanowski JQ, Lee VM: Pesticide exposure exacerbates alpha-synucleinopathy in an A53T transgenic mouse model. Am J Pathol 2007, 170:658-666.

180. Dauer W, Kholodilov N, Vila M, Trillat A-C, Goodchild R, Larsen KE Staal R, Tieu K, Schmitz Y, Yuan CA, Rocha M, Jackson-Lewis V, Hersch S, Sulzer D, Przedborski S, Burke R, Hen R: Resistance of $\alpha$ synuclein null mice to the parkinsonian neurotoxin MPTP. Proc Natl Acad Sci USA 2002, 99: | 4524-| 4529.

18I. Klivenyi P, Siwek D, Gardian G, Yang L, Starkov A, Cleren C, Ferrante RJ, Kowall NW, Abeliovich A, Beal MF: Mice lacking alpha-synuclein are resistant to mitochondrial toxins. Neurobiol Dis 2006, 2 I:54I-548.

182. Drolet RE, Behrouz B, Lookingland KJ, Goudreau JL: Mice Lacking [alpha]-Synuclein have an Attenuated Loss of Striatal Dopamine Following Prolonged Chronic MPTP Administration. Neurotoxicology. 2004, 25(5):761-769.

183. Devi L, Raghavendran V, Prabhu BM, Avadhani NG, Anandatheerthavarada HK: Mitochondrial import and accumulation of alphasynuclein impair complex I in human dopaminergic neuronal cultures and Parkinson disease brain. I Biol Chem 2008, 283:9089-9100.

184. Snyder H, Mensah K, Theisler C, Lee J, Matouschek A, Wolozin B: Aggregated and Monomeric alpha -Synuclein Bind to the S6
Proteasomal Protein and Inhibit Proteasomal Function. J Biol Chem 2003, 278: II753-11759.

185. Stefanis L, Larsen KE, Rideout HJ, Sulzer D, Greene LA: Expression of A53T mutant but not wild-type alpha-synuclein in PCI 2 cells induces alterations of the ubiquitin-dependent degradation system, loss of dopamine release, and autophagic cell death. J Neurosci 200I, 2 I:9549-9560.

186. Tanaka Y, Engelender S, Igarashi S, Rao RK, Wanner T, Tanzi RE, Sawa $A L$, Dawson $V$, Dawson TM, Ross CA: Inducible expression of mutant $\{$ alpha\}-synuclein decreases proteasome activity and increases sensitivity to mitochondria-dependent apoptosis. Hum Mol Genet 2001, 10:919-926.

187. Cuervo AM, Stefanis L, Fredenburg R, Lansbury PT, Sulzer D: Impaired degradation of mutant alpha-synuclein by chaperone-mediated autophagy. Science 2004, 305: I 292-। 295.

188. Yang Q, She H, Gearing M, Colla E, Lee M, Shacka JJ, Mao Z: Regulation of Neuronal Survival Factor MEF2D by ChaperoneMediated Autophagy. Science 2009, 323: I24- I 27.

189. Giasson BI, Duda JE, Murray IV, Chen Q, Souza JM, Hurtig HI, Ischiropoulos $\mathrm{H}$, Trojanowski JQ, Lee VM: Oxidative damage linked to neurodegeneration by selective alpha-synuclein nitration in synucleinopathy lesions. Science 2000, 290:985-989.

190. Gomez-Santos C, Ferrer I, Reiriz J, Vinals F, Barrachina M, Ambrosio $S:$ MPP+ increases alpha-synuclein expression and ERK/MAP. kinase phosphorylation in human neuroblastoma SH-SY5Y cells. Brain Res 2002, 935:32-39.

191. Sherer TB, Betarbet R, Stout AK, Lund S, Baptista M, Panov AV, Cookson MR, Greenamyre JT: An in vitro model of Parkinson's disease: linking mitochondrial impairment to altered alphasynuclein metabolism and oxidative damage. J Neurosci. 2002, 22( I 6):7006-70I5.

192. Paxinou E, Chen Q, Weisse M, Giasson BI, Norris EH, Rueter SM, Trojanowski JQ, Lee VMY, Ischiropoulos H: Induction of \{alpha\}Synuclein Aggregation by Intracellular Nitrative Insult. Neurosci. 200I, 2 I(20):8053-806I.

193. Hodara R, Norris EH, Giasson BI, Mishizen-Eberz AJ, Lynch DR, Lee VMY, Ischiropoulos H: Functional Consequences of \{alpha\}Synuclein Tyrosine Nitration: diminished binding to lipid vesicles and increased fibril formation. J Biol Chem 2004, 279:47746-47753.

194. Krishnan S, Chi EY, Wood SJ, Kendrick BS, Li C, Garzon-Rodriguez W, Wypych J, Randolph TW, Narhi LO, Biere AL, Citron M, Carpenter JF: Oxidative dimer formation is the critical rate-limiting step for Parkinson's disease alpha-synuclein fibrillogenesis. Biochemistry 2003, 42:829-837.

195. Yamin G, Uversky VN, Fink AL: Nitration inhibits fibrillation of human alpha-synuclein in vitro by formation of soluble oligomers. FEBS lett 2003, 542:|47-I52.

196. Souza JM, Giasson BI, Chen Q, Lee VM, Ischiropoulos H: Dityrosine cross-linking promotes formation of stable alpha -synuclein polymers. Implication of nitrative and oxidative stress in the pathogenesis of neurodegenerative synucleinopathies. J Biol Chem 2000, 275: 18344-18349.

197. Norris EH, Giasson BI, Ischiropoulos H, Lee VM: Effects of oxidative and nitrative challenges on alpha-synuclein fibrillogenesis involve distinct mechanisms of protein modifications. Biol Chem 2003, 278:27230-27240.

198. Paik SR, Shin HJ, Lee JH: Metal-catalyzed oxidation of alphasynuclein in the presence of Copper(II) and hydrogen peroxide. Arch Biochem Biophys 2000, 378:269-277.

199. Conway KA, Rochet JC, Bieganski RM, Lansbury PT Jr: Kinetic stabilization of the alpha-synuclein protofibril by a dopaminealpha-synuclein adduct. Science 200I, 294: I346-I349.

200. Norris EH, Giasson BI, Hodara R, Xu S, Trojanowski JQ, Ischiropoulos $\mathrm{H}$, Lee VM: Reversible inhibition of alpha-synuclein fibrillization by dopaminochrome-mediated conformational alterations. I Biol Chem 2005, 280:2I2I 2-2I2I9.

20I. Mazzulli JR, Armakola M, Dumoulin M, Parastatidis I, Ischiropoulos H: Cellular Oligomerization of \{alpha\}-Synuclein Is Determined by the Interaction of Oxidized Catechols with a C-terminal Sequence. J Biol Chem 2007, 282:3162I-31630.

202. Herrera FE, Chesi A, Paleologou KE, Schmid A, Munoz A, Vendruscolo M, Gustincich S, Lashuel HA, Carloni P: Inhibition of alphaSynuclein Fibrillization by Dopamine Is Mediated by Interactions with Five C-Terminal Residues and with E83 in the NAC Region. PLOS ONE 2008, 3:e3394. 
203. Mazzulli JR, Mishizen AJ, Giasson BI, Lynch DR, Thomas SA, Nakashima A, Nagatsu T, Ota A, Ischiropoulos H: Cytosolic catechols inhibit alpha-synuclein aggregation and facilitate the formation of intracellular soluble oligomeric intermediates. J Neurosci 2006, 26:10068-10078.

204. Nagatsu T: Change of tyrosine hydroxylase in the parkinsonian brain and in the brain of MPTP-treated mice as revealed by homospecific activity. Neurochem Res 1990, 15:425-429.

205. Grune T, Shringarpure R, Sitte N, Davies K: Age-related changes in protein oxidation and proteolysis in mammalian cells. J Gerontol A Biol Sci Med Sci. 200I, 56(I I):B459-B467.

206. Stadtman ER, Levine RL: Protein oxidation. Ann N Y Acad Sci 2000, 899: $191-208$.

207. Oliver CN, Ahn BW, Moerman EJ, Goldstein S, Stadtman ER: Agerelated changes in oxidized proteins. J Biol Chem 1987, 262:5488-5491.

208. Smith CD, Carney JM, Starke-Reed PE, Oliver CN, Stadtman ER, Floyd RA, Markesbery WR: Excess brain protein oxidation and enzyme dysfunction in normal aging and in Alzheimer disease. Proc Natl Acad Sci USA I99I, 88: I0540- 10543.

209. Ding Q, Dimayuga E, Keller JN: Proteasome regulation of oxidative stress in aging and age-related diseases of the CNS. Antioxid Redox Signal 2006, 8: 163-172.

210. Farout $L$, Friguet $B$ : Proteasome function in aging and oxidative stress: implications in protein maintenance failure. Antioxid Redox Signal 2006, 8:205-216.

211. Cuervo AM, Dice JF: Age-related decline in chaperone-mediated autophagy. J Biol Chem 2000, 275:3 I505-3I5I3.

212. Donati A, Cavallini G, Paradiso C, Vittorini S, Pollera M, Gori Z, Bergamini $\mathrm{E}$ : Age-related changes in the regulation of autophagic proteolysis in rat isolated hepatocytes. I Gerontol A Biol Sci Med Sci 200I, 56(7):B288-B293.

213. Dice JF: Altered degradation of proteins microinjected into senescent human fibroblasts. I Biol Chem. 1982, 257(24): | 4624- |4627.

214. Martinez-Vicente M, Sovak G, Cuervo AM: Protein degradation and aging. Exp Gerontol 2005, 40:622-633.

215. Terman A: The effect of age on formation and elimination of autophagic vacuoles in mouse hepatocytes. Gerontology 1995, 4 I (Suppl 2):3 I 9-326.

216. Sitte N, Merker K, Von Zglinicki T, Davies KJ, Grune T: Protein oxidation and degradation during cellular senescence of human BJ fibroblasts: part II-aging of nondividing cells. Faseb J 2000, | 4:2503-25 I0.

217. Sullivan PG, Dragicevic NB, Deng JH, Bai $Y$, Dimayuga E, Ding $Q$, Chen Q, Bruce-Keller AJ, Keller JN: Proteasome inhibition alters neural mitochondrial homeostasis and mitochondria turnover. J Biol Chem 2004, 279:20699-20707.

218. LaVoie MJ, Hastings TG: Dopamine quinone formation and protein modification associated with the striatal neurotoxicity of methamphetamine: evidence against a role for extracellular dopamine. J Neurosci. 1999, I 9(4): | 484- I49|.

219. LaVoie MJ, Ostaszewski BL, Weihofen A, Schlossmacher MG, Selkoe DJ: Dopamine covalently modifies and functionally inactivates parkin. Nat Med 2005, I I: I 2| 4- I 22 I.

220. Hastings TG, Lewis DA, Zigmond MJ: Role of oxidation in the neurotoxic effects of intrastriatal dopamine injections. Proc Natl Acad Sci USA 1996, 93:1956-1961.

221. Caudle WM, Richardson JR, Wang MZ, Taylor TN, Guillot TS, McCormack AL, Colebrooke RE, Di Monte DA, Emson PC, Miller GW: Reduced vesicular storage of dopamine causes progressive nigrostriatal neurodegeneration. J Neurosci 2007, 27:8|38-8|48.

222. Rosenberg PA: Catecholamine toxicity in cerebral cortex in dissociated cell culture. J Neurosci. I988, 8(8):2887-2894.

223. Zecca L, Zucca FA, Albertini A, Rizzio E, Fariello RG: A proposed dual role of neuromelanin in the pathogenesis of Parkinson's disease. Neurology. 2006, 67(7 Suppl 2):S8-SII.

224. D'Amato RJ, Lipman ZP, Snyder SH: Selectivity of the Parkinsonian Neurotoxin MPTP: toxic metabolite MPP+ binds to neuromelanin. Science 1986, 23 I:987-989.

225. Luigi Zecca Casella L, Albertini A, Bellei C, Zucca FA, Engelen M, Zadlo A, Szewczyk G, Zareba M, Sarna T: Neuromelanin can protect against iron-mediated oxidative damage in system modeling iron overload of brain aging and Parkinson's disease. I Neurochem. 2008, I06(4): |866-1875.
226. Faucheux BA, Martin ME, Beaumont C, Hauw J, Agid Y, Hirsch EC: Neuromelanin associated redox-active iron is increased in the substantia nigra of patients with Parkinson's disease. J Neurochem. 2003, 86(5): I|42-I|48.

227. Guelman LR, Pagotto RM, Di Toro CG, Zieher LM: Deferoxamine antioxidant activity on cerebellar granule cells [gamma]irradiated in vitro. Neurotoxicol Teratol 2004, 26:477-483.

228. Santiago M, Matarredona ER, Granero L, Cano J: Neuroprotective Effect of the Iron Chelator Desferrioxamine Against MPP+ Toxicity on Striatal Dopaminergic Terminals. J Neurochem. 1997, 68(2):732-738.

229. Shachar DB, Kahana N, Kampel V, Warshawsky A, Youdim MBH: Neuroprotection by a novel brain permeable iron chelator, VK-28, against 6-hydroxydopamine lession in rats. Neuropharmacology 2004, 46:254-263.

230. Ben-Shachar D, Eshel G, Finberg JP, Youdim MB: The iron chelator desferrioxamine (Desferal) retards 6-hydroxydopamineinduced degeneration of nigrostriatal dopamine neurons. J Neurochem 1991, 56:144I-I444.

23I. Hirsch E, Graybiel AM: Melanized dopaminergic neurons are differentially susceptible to degeneration in Parkinson's disease. Nature 1988, 334:345-348.

232. Fasano M, Giraudo S, Coha S, Bergamasco B, Lopiano L: Residual substantia nigra neuromelanin in Parkinson's disease is cross-linked to [alpha]-synuclein. Neurochem Int 2003, 42:603-606

233. Halliday GM, Ophof A, Broe M, Jensen PH, Kettle E, Fedorow $H$, Cartwright MI, Griffiths FM, Shepherd CE, Double KL: \{alpha\}Synuclein redistributes to neuromelanin lipid in the substantia nigra early in Parkinson's disease. Brain 2005, I 28:2654-2664.

234. Fowler DM, Koulov AV, Alory-Jost C, Marks MS, Balch WE, Kelly JW: Functional Amyloid Formation within Mammalian Tissue. PLoS biology 2006, 4:e6.

235. Hurbain I, Geerts WJC, Boudier T, Marco S, Verkleij AJ, Marks MS, Raposo G: Electron tomography of early melanosomes: Implications for melanogenesis and the generation of fibrillar amyloid sheets. Proc Natl Acad Sci USA 2008, I05: I 9726- 1973 I.

236. Fedorow H, Pickford R, Hook JM, Double KL, Halliday GM, Gerlach $M$, Riederer P, Garner B: Dolichol is the major lipid component of human substantia nigra neuromelanin. J Neurochem 2005, 92:990-995.

237. Marsden CD: Pigmentation in the nucleus substantiae nigrae of mammals. J Anat I96I, 95:256-26I.

238. Masliah E, Rockenstein E, Veinbergs I, Mallory M, Hashimoto $M$ Takeda A, Sagara Y, Sisk A, Mucke L: Dopaminergic loss and inclusion body formation in alpha-synuclein mice: implications for neurodegenerative disorders. Science 2000, 287: $1265-1269$

239. Tofaris GK, Garcia Reitbock P, Humby T, Lambourne SL, O'Connell M, Ghetti B, Gossage H, Emson PC, Wilkinson LS, Goedert M, Spillantini MG: Pathological changes in dopaminergic nerve cells of the substantia nigra and olfactory bulb in mice transgenic for truncated human alpha-synuclein(I-120): implications for Lewy body disorders. J Neurosci 2006, 26:3942-3950.

240. Richfield EK, Thiruchelvam MJ, Cory-Slechta DA, Wuertzer C, Gainetdinov RR, Caron MG, Di Monte DA, Federoff HJ: Behavioral and Neurochemical Effects of Wild-Type and Mutated Human [alpha]-Synuclein in Transgenic Mice. Exp Neurol 2002, I 75:35-48. 